\title{
Review of the policy process in Bangladesh following ICPD
}

\author{
Nancy J. Piet-Pelon \\ Ubaidur Rob \\ Population Council \\ Syeda Nahid Mukith Chowdhury \\ Abul Barkat \\ Sushil Ranjan Howlader
}

See next page for additional authors

Follow this and additional works at: https://knowledgecommons.popcouncil.org/departments_sbsr-rh

Part of the Demography, Population, and Ecology Commons, Family, Life Course, and Society Commons, International Public Health Commons, and the Women's Health Commons How does access to this work benefit you? Let us know!

\section{Recommended Citation}

Piet-Pelon, Nancy J., Ubaidur Rob, Syeda Nahid Mukith Chowdhury, Abul Barkat, Sushil Ranjan Howlader, Sharif M.I. Hossain, Ismat Bhuiya, and Siraj-us-Saleheen. 1999. "Review of the policy process in Bangladesh following ICPD." Dhaka: Population Council. 


\section{Authors}

Nancy J. Piet-Pelon, Ubaidur Rob, Syeda Nahid Mukith Chowdhury, Abul Barkat, Sushil Ranjan Howlader, Sharif M.I. Hossain, Ismat Bhuiya, and Siraj-us- Saleheen 


\section{Review of the Policy Process in Bangladesh Following ICPD}

January 1999

Bangladesh 


\section{Review of the Policy Process in Bangladesh Following ICPD}

Nancy J. Piet Pelon, Ubaidur Rob, Syeda Nahid Mukith Chowdhury, Abul Barkat, S. R. Howladar, Sharif Mohammed Ismail Hossain, Ismat Bhuiyan, Siraj-us-Saleheen

Population Council, Bangladesh

January 1999 


\section{Table of Contents}

Acknowledgement iv

Introduction $\quad 1$

The Review Process Methodology 3

Pre-Cairo Policy Environment in Bangladesh 3

The PrepCom and ICPD Delegations $\quad 7$

Post Cairo 9

Policy Changes 13

Government-NGO-Private Sector Collaboration $\quad 14$

$\begin{array}{ll}\text { Conclusions } & 17\end{array}$

References 19

Appendices

Appendix A List of Persons Contacted 25

Appendix B Guideline for Discussion with the Key Personnel on Achievement of Bangladesh National Program since The ICPD'94: Policy and Program Level Changes 27

Appendix C $\quad$ List of Bangladeshi Delegates Attending ICPD'94 29

Appendix D Chronology of Major Events in Bangladesh both Pre and Post-ICPD'94 33

Appendix E Policies and programs in line with ICPD Programme of Action and Major Policy Changes 35

List of Abbreviations 


\section{Acknowledgement}

The study was supported by Population Council and UNFPA. This document brings together all the key events that took place and experience gained before and after Cairo'94, which culminated in policy changes in Bangladesh. The paper is an effort to look at the process of changes in the policy and programs, and to critically evaluate what has Cairo influenced in Bangladesh at various policy and program levels, and to what extent.

We would like to acknowledge the contributions of the Bangladesh delegates of the Cairo Conference and key policy people for sharing their experience and views with us. Owing to the short time frame we could not reach all the delegates, which other wise would have enriched the paper.

We also gratefully acknowledge the valuable support and encouragement received from Dr. Saroj Pachauri, Regional Director, Population Council - South and East Asia for taking the main initiative for preparing this document. 


\section{Introduction}

The International Conference on Population and Development (ICPD) in Cairo in 1994 was the culmination of months of national and international discussions. The issues, which had been crafted into a Programme of Action, represented a potential shift in thinking which would revolutionize the way signing governments viewed their population problems. In fact, by the end of the conference it would no longer be considered appropriate to think of population growth as a 'problem', let alone one which would be solved by targeted family planning programs. Instead, delegates would leave the conference espousing a new paradigm and a broad definition of what people, especially women, should expect from their national health services. The new approach demanded that governments think of women in a holistic fashion. Governments were encouraged to recognize that the improved health status of women could only be achieved by a life cycle approach and that health depended not only on good family planning information and services. Rather, women's empowerment in all spheres - legal status, employment, and education - had to be achieved simultaneously. The evolution of this thinking had roots in the experience of many countries that had worked for decades to provide better lives for their citizens. Many had tried to ensure the achievement of their development goals through assertive family planning programs designed to arrest population growth.

Bangladesh is a unique case in point. It did have an internationally recognized family planning program with positive influences on the health of women and their children. But, it also had several development programs that went far beyond family planning microcredit and education for girls were two that had been successful in many communities and had received international recognition for their success.

By the beginning of the nineties decade, the Bangladesh family planning program had gone through many changes. Its achievements, in demographic terms, had exceeded the expectations of many. Though the economic situation of the country remained precarious, the contraceptive prevalence rose steadily from seven in the mid-seventies to 40 by 1991. Instead of having 6.3 children in their lifetime, the average woman in Bangladesh could expect to have 4.3. Yet, this success did not deflect criticism of the program from within and outside of the country. Rather, the Ministry of Health and Family Welfare (MOHFW), the NGOs who provided family planning services, technical assistance agencies and the development partners, were joined in concern for the future of the program. Before ICPD was more than a distant date on the calendar, the family planning community of Bangladesh had committed itself to revamping its program with an emphasis on improving quality, expanding access, and developing sustainable systems. ${ }^{1}$

The process of program redefinition was difficult and fraught with challenge. But the course had been set to greatly improve the approach of the family planning and

\footnotetext{
1 In fact, the three guiding principles of the USAID assistance to Bangladesh were: quality, expanding access and sustainability, known as the QES. The Population IV project funded by The World Bank also emphasized quality issues, improved method mix, extensive maternal health services, all in the context of gender equity. The government at the time echoed these strategies.
} 
maternal and child health $(\mathrm{MCH})$ programs. The critical question is -- Did ICPD influence this process or would it have occurred in the natural course of program improvement? Key informant interviews and a review of documentation yielded a full range of responses. There were those who gave great credit to ICPD for influencing the present policy climate in Bangladesh. Others insisted that the program would be where it is today without ICPD. Most interviewees took a middle ground, agreeing that the process which lead to ICPD globally was an opportunity to sensitize many beyond the Bangladesh family planning community to the issues of reproductive health. It was characterized as a 'leavening of an on-going process', a 'boost', it 'brought together various factions', it 'encouraged' the nascent changes.

What was happening in Bangladesh during the ICPD planning process that led to these very different responses today? There are three principle issues identified: (i) The program climate in Bangladesh was in the process of change. The government recognized the importance of continuing to have family planning goals that would achieve the long-set demographic target of reaching replacement fertility by 2005 . But the MOHFW had also been influenced by calls for improvement in quality of services. They recognized that the $\mathrm{MCH}$-based family planning program, while successful, had reached a crossroads. In order to move forward changes in emphasis and approach were required. The Programme of Action of ICPD reflected many of the changes that Bangladesh considered pre-ICPD. (ii) The timing of ICPD was excellent for Bangladesh. The programs supported by both the major donor to the national family planning program, USAID, plus the World Bank and the development partners were coming to the end and plans were in process for the next programs of assistance. The Programme of Action of ICPD provided a framework that tied together the pre-ICPD work of the MOHFW and donors to identify priority concerns of the program with a possible agenda for action. (iii) The unique delegation sent from Bangladesh for both PrepCom and the conference itself was comprised of many of the program's 'stakeholders'. The MOHFW deliberately selected a delegation that represented NGOs, advocacy groups and technical assistance agencies. This balance was critical during the ICPD process and afterwards.

ICPD was far from the first international conference where Bangladesh participated. Nor was it the first time that their views were heard. Jyoti Shankar Singh (1998) comments on the influence of Bangladesh on the Bucharest conference in 1974:

Bangladesh, which had become independent at the end of 1971 and as one of the poorest countries in the world was struggling with urgent and difficult problems of development, made one of the most forthright statements at the Conference: 'our demographic situation leaves us with no alternative but to try to contain and curb our population growth by all possible means and as quickly as possible.'

Bangladesh continued to participate in future international conferences, including Mexico City in 1984 where it was represented by a small delegation that was half NGO representation and half government. 
By the time ICPD occurred in September of 1994, Bangladesh had been represented by a unique blend of delegates through the PrepCom process. Because of their active participation in the preparatory phases, the ICPD Programme of Action held no surprises for Bangladesh. Rather it was an articulation of what the country and each organization represented in Cairo sought to achieve for the women of the country. Following ICPD, the policy and programming environment in Bangladesh grew richer and broader. Thus, the greatest contribution of the ICPD to Bangladesh was in its timing and its focus on a holistic approach to health that boosted the dynamic process already well underway.

\section{The $R_{\text {eview }}$ Process Methodology}

The report is mainly based on secondary data collected through extensive review of all policy and program related documents published prior to and after ICPD. Primary information were collected through meetings and interview of key GoB, NGO personnel, Donors, and delegates who attended the PrepCom meetings and ICPD conference (Appendix A).

Discussion with the key personnel focused on their experience and involvement during the preparatory phase of Cairo, the conference itself, and the post Cairo activities at the national level. Of particular interest were their views about changes brought about at the policy level and process involved; steps undertaken to implement the policy change; outcomes and barriers encountered; and, whether any of the components recommended in the program of action existed in the national policy and program prior to Cairo and were only reinforced by the conference (Appendix B).

\section{Pre-Cairo Policy Environment in Bangladesh}

The success the Bangladesh family planning program enjoyed was based on 30 years of experimentation and experience. During that time, Bangladesh proved that despite extremes of economic deprivation family planning programs could be implemented if there was a strong political will. The priority and focus on population issues remained a constant through periods of political instability. Strong and steadfast support was provided at the policy level from all the governments since Independence. The policy was based on the need to curb population growth to achieve development objectives.

The program has grown from a small clinic-based initiative to a multi-sectoral nationwide effort. It had its beginnings before the Independence of the country, starting in 1953 on the initiative of professionals and social workers that founded the Family Planning Association. During the sixties, the program grew from small clinic base to include community workers. Emphasis in the decade before Independence included clinical services, communication of the family planning ideals and expanded outreach. Choice of contraceptives was limited to intra uterine device (Lippes Loop), sterilization 
(with an equal emphasis on male and female sterilization), condoms, foam, jelly and diaphragms. Monetary incentives were included to encourage couples to select the clinical methods.

The program was in hiatus during the Liberation struggle. After Liberation, however, the government affirmed its concern that population growth was the number one problem of the country. Subsequently, it set a course to overcome the growth of population through family planning services that were based on maternal and child health. Throughout the eighties, the program grew - adding female paramedics as service providers, establishing communication with the community through a large cadre of female front line workers, and providing menstrual regulation services to support the program. All of these efforts led to the demographic success of the program. Though the program had a demographic target base, it cannot be denied that the health of some women and children was also improved through the $\mathrm{MCH}$ efforts. Pregnancy and delivery care was improved for some women through services offered at the Primary Health Care level in thousands of Family Welfare Centers. TBA and Family Welfare Visitors were trained in large numbers to provide safe deliveries. However, these services failed to reach the majority of women. Nationwide immunization coverage and work vastly improved children's health on the control of common childhood ailments - acute respiratory infections and diarrhoeal diseases.

Throughout its long history, the program maintained two positive features which contributed directly to its success: (i) the inclusion of NGOs, supported mainly by USAID assistance, who developed effective community-level family planning services and clinical services for sterilization and (ii) constant monitoring, evaluation and research by survey, operations and experimental research. The willingness of the leaders of the Bangladesh national program to encourage partnership of NGOs and to allow their program to be scrutinized through various evaluative processes created a climate where innovation was possible. Consequently, Bangladesh stands out among its neighbors as a country which effectively used technical assistance to improve its program. Another salient feature of the program was the uninterrupted donor support it received. Thus, in spite of government changes throughout the decades from Independence to the present day, the population efforts received sufficient support from international donors to experiment with new ideas and sustain program momentum. Whenever either the government or the NGOs wished to try innovations - and there were many - the donors (now commonly called the development partners) stood ready to assist.

There were two negative aspects of the program, however, which impeded its success: (i) the structure of the program and (ii) the potential for it to be donor driven. In the First Five Year Plan of Bangladesh (1973-78), an organizational structure was created. A separate population control and family planning division was set up within the Ministry of Health and Family Planning. This division was responsible for implementing the family planning and $\mathrm{MCH}$ programs. At the same time, the Health Directorate was responsible for curative services and took no direct responsibility for family planning. Over the years, the separation between the two Directorates grew sharper and many 
conflicts arose, particularly when Health Directorate medical officers were seconded to the family planning program to provide clinical sterilization services.

Donor funds were continuously available to the program but their funds were sometimes considered a two-edged sword. Critics felt that donors too often determined the course of the program. Often when the government faltered or was in transition, the donors provided direction. For example, it was the donors who raised the main concerns about flagging quality. Yet, at the same time, it was the donors who stood ready to provide the funds and technical assistance to make the needed course corrections.

Bangladesh family planning policy makers steadfastly maintained throughout the decades that development goals could be achieved only if population growth was arrested. These views were strongly supported by donors. Thus, the policies were family planning target focused even though the improved health of women and children always remained an important concern. Success was measured in traditional ways reduction of maternal mortality rate (MMR) and infant mortality rate (IMR), increases in contraceptive prevalence rate (CPR) and lowering of total fertility rate (TFR). The reduction of population growth and the slowing of population momentum were the ultimate measures of success. The written policies reflected this and the various five year plans set achievement targets for all of these indicators. Yet, already the Fourth Five Year Plan emphasized quality concerns and stressed the need for improved integration of health and family planning services at the community and primary health care level. To achieve this goal, the Plan recommended strengthening the $\mathrm{MCH}$ component, expanding and improving the clinical contraceptive services, improving quality of care by augmenting the screening of clients, counseling and follow-up.

However, in spite of uninterrupted efforts to provide family planning and $\mathrm{MCH}$ services by the early nineties, the program was stagnating. It was at this point that the government took the bold steps, again strongly supported by the donor community, that would lead them eventually to full participation in ICPD and acceptance of the agenda set out in the Programme of Action. Faced with the stagnation of the family planning program, the MOHFW initiated a dialogue with all segments of the civil society development partners, NGOs, technical assistance agencies, women's advocacy groups, and concerned professionals - to identify future challenges and develop a time-bound plan of action to meet those. The main concern centered on two issues: the health of women and children had not improved to desired levels and the program had to accelerate in sustainable ways to meet the service needs of the increasing number of women who would soon require services. It was mainly USAID ${ }^{2}$, with the MOHFW, who lead the rest of the population community to consider the problems of the program that needed to be overcome. These were identified as ten priority areas: relationship between non-medical and medical personnel in the family planning wing; status of

\footnotetext{
2 It should not be forgotten that the global USAID, not only the mission in Bangladesh, was going through major changes during this same period. Due to leadership changes from the Administration of the United States to USAID itself, and its Office of Population, embracing the broader agenda of reproductive health became possible. This represented quite a shift from USAID's previous stress on pure family planning programs. A USAID cooperating agency meeting held in early 1994 had several reproductive health issues on the agenda, e.g. post-abortion care and female genital mutilation. Emphasis was placed on quality as they introduced a new initiative called MAQ - management for quality. This broadening of the agenda by Washington, allowed the USAID mission in Bangladesh to fully support - and often provide the leadership for - the policy shifts in Bangladesh.
} 
family planning staff funded under the development budget; inadequate training of all workers; NGO/government division of labor and coordination; urban health and family planning; pricing and cost recovery; relationship between the health and family planning wings; accountability of all workers; information for program management; and clinical contraception.

Based on these findings, the MOHFW initiated a Plan of Action based on identified future challenges. This was disseminated during the Family Planning Fortnight in December 1993 where the program gaps and suggested alternative actions were shared with all stakeholders throughout the country. The plan of action of the future challenges identified nine priority areas for immediate action: increasing the use of clinical methods; intensifying program efforts in low-performing areas; improving coverage of undeserved groups; strengthening family planning services in the Health Directorate; improving performance and follow-up; accelerating IEC and community mobilization; carrying out critical training; enhancing collaboration between government and NGOs; and strengthening $\mathrm{MCH}$ and reproductive health activities. This mention of reproductive health was new and represented a strongly held belief that the family planning focus of the country was insufficient to meet desired goals, particularly for improved women's health. In June 1994, a National Steering Committee was formed under the chairmanship of the Health Minister. The committee included representation from the government, NGOs and resource institutions. Their role was to review and approve action plans; oversee the implementation progress; provide policy guidance, discuss responsibilities and resources among NGOs and donors; and, resolve issues that required interagency collaboration at the national level.

At the same time that the issues put forward in the future challenges were being debated in Bangladesh, ICPD was being planned. Clearly the Bangladesh program was already set on a course which would lead naturally into the agenda which would be discussed at ICPD. The outcome of the working group reports on the future challenges were incorporated in the ICPD draft country paper. This linkage and transfer of ideas occurred because the same people were involved in both the ICPD PrepCom committees and the future challenges.

The family planning program in Bangladesh never operated in isolation. Other elements effecting women's empowerment were being tackled by a combination of government and NGOs. Concern for women had its roots in the aftermath of Liberation. The struggle during the Liberation Period (1971) had a particularly deleterious effect on the lives of women and children. Many were forced from the safe havens of their villages and migrated around the country, and beyond, to seek shelter from the military engagements. When Independence came, many women were without the protection of their families or communities. The government, with the help of national and international NGOs, worked together toward improving the status - first of dispossessed women -- and later of all women. Thus, education, employment and legal status were all priority areas of concern and work. Before ICPD, the formal and nonformal education of girls was a strong development program, as were microcredit programs that focused on women, and improved legal status. 
In the education sector several accomplishments can be noted. Equal opportunity of men and women is delineated as a fundamental state policy of Bangladesh. The gender gap in enrollment in primary and secondary education has been reduced. This rapid change is due to a concerted effort that provides a stipend for girls' secondary education. Primary education for boys and girls was made compulsory in 1993 with an aim to provide education for all by the year 2000. Boys and girls from poor families receive food under the Food for Education program. This as increased enrollments by 87 percent. A special scholarship program for girl students has been introduced at the secondary level. This has increased enrollment and reduced dropouts. Secondary education for girls is free outside of municipal areas. One separate school for girls will be established in each thana. A single girl child is given an opportunity to study to degree level, all free of cost.

The credit programs for women established in Bangladesh have received international acclaim. The Bangladesh Rural Development Board, Grameen Bank, BRAC and Swanirvar are among those providing extensive credit opportunities. About ten million women are the beneficiaries of these credit programs.

The legal status of women in Bangladesh is protected by the Constitution that guarantees equal rights for both genders. Though insufficiently enforced, there are several laws that support women's rights. Ross et al. (1995) write that “...The recent 1995 Ordinance on the Oppression of Women and Children provides penalties ranging from rigorous imprisonment for 7-14 years with fine, to life in prison with fine-or even death depending on the nature of the crime for kidnapping for unlawful or immoral purpose, trafficking in women, causing death or grievous injury to a woman for dowry, for committing or attempting to commit rape." Yet, they go on to remind that the law projects women in 'public life' while most women are actually governed by what happens in their 'private life'.

Consequently, well-before the delegations from Bangladesh were formed to attend the PrepCom meetings and ICPD itself, the issues of women's empowerment had been national issues of concern and attention. What were lacking were a strong integration of these programs and a view of holistic view of women.

\section{The Prep Com and ICPD Delegations}

During the future challenges exercise the government worked closely with the family planning NGOs, which had traditionally been funded by USAID. Thus, when forming the delegations to attend the PrepCom and the ICPD itself, the MOHFW included these partners in the delegation. ${ }^{3}$ During interviews many of the key informants noted that the Secretary of the MOHFW during that time was known as a consensus builder, willing to be inclusive of all who worked on family planning and women's issues. That desire for consensus greatly influenced the selection of the delegation. UNFPA was also influential

${ }^{3}$ It should be reiterated, however, that this is not the first time Bangladesh included NGOs as part of the national delegations. The same was true for the Mexico City Conference. 
in the preparation for Cairo and the composition of the delegation. There was a particular desire to ensure that women's voices were represented. Thus, invitations were also extended to women's advocacy groups. All were part of the national delegation (Appendix C). One of the great contributions that Bangladesh made at the preparatory phase of ICPD was to send this balanced delegation, where NGOs and women's advocates were equal partners with government colleagues. As one NGO interviewee stated: "We were looked upon by the other delegations with some interest. Many were asking how we NGO representatives were equal members of our national delegation."

The Bangladesh delegations were very active in PrepCom II and III. One of the women members was vice-chairperson of the group that developed important sections of the Programme of Action. Through this delegate, and others during the PrepCom process, Bangladesh had a leadership role in negotiating with other countries to finalize a critical element of the Programme of Action.

To highlight the importance of the conference, the leadership of MOHFW also planned that the Prime Minister would head the delegation. It had further been arranged that she would speak at the opening session. The inclusion of the Prime Minister would illustrate by fine example the total government commitment to the issues of population and development.

However, there was one shortcoming during the planning. The Programme of Action, shared with countries prior to ICPD, was that it was not vetted to a wide audience at the country level. The Bangladesh country report, which had been shared to a wider audience, was a reflection of the future challenges and thus, mainly, family planning focused - though reproductive health had been mentioned as an important part of the future. Consequently there was some gap between the agenda of the Programme of Action and the specific plans in Bangladesh. This gap was mainly in the wider agenda of development and empowerment issues. Yet, because so many in the Bangladesh delegation had taken an active part in the preparatory phases of ICPD, there were no real surprises in the final Programme of Action document.

There was also one area of concern - abortion. The national program in Bangladesh has had menstrual regulation services since the mid-seventies, provided in government and selected NGO sites. This service is provided in a conservative legal setting - abortion is illegal except to save the life of the mother. The government has been careful to keep a distinction between menstrual regulation, which is performed without first establishing pregnancy, and abortion. Thus, in international forums, their stand on abortion reflects the country laws.

The Bangladesh delegation played an active role in ICPD, though they themselves noted during interviews that they felt their status was diminished by the absence of their Prime Minister. In early arrangements it had been agreed that the Prime Minister would speak at the opening session. This would have brought tremendous positive attention to the Bangladesh program. When the Prime Minister was unable to attend, the delegation strategized about ways to bring the lessons of ICPD back to Bangladesh. A significant decision was to invite Dr. Nafis Sadik to Bangladesh to meet the Prime Minister and 
discuss the Programme of Action. Thus, if the Prime Minister would not come to ICPD, in a sense, ICPD would come to her. Dr. Sadik accepted the invitation and plans were formulated even before leaving Cairo to use the opportunity to hold a national conference on safe motherhood. While the Prime Minister and some of her advisers may have been reluctant to learn about the complete Programme of Action, particularly abortion related issues, the delegation leadership was sure she would welcome a meeting dedicated to saving the mothers of Bangladesh.

\section{Post Cairo}

Regarding the results of ICPD, Singh (1998) writes:

The concept of development was broadened by Cairo to include the strategies of sustainability (sustained economic growth and long-term sustainability in production and consumption) and a more integrated approach to population and development concerns. While urging the countries to give greater attention to population trends in relation to development, the Cairo Conference proposed a comprehensive package of policy measures: economic development and poverty alleviation; the improvement of women's status; universal access to quality primary education and primary health care, including reproductive health and family planning services; the reduction of infant, child and maternal mortality; and human resource development. By focusing attention on 'unmet needs' of couples and individuals and by criticizing the system of quotas and targets, the conference clearly rejected the top-down approach in policy formulation and brought the concept of human rights, particularly those of women, to the fore. In taking these positions, Cairo marked a radical departure from the previous two population conferences.

What happened next in Bangladesh that created the fundamental shifts in the program which are much in evidence today? Certainly there was a flurry of meetings, task force reports many focused on sharing the lessons of ICPD but also to continue the on-going policy work of the future challenges. (Appendix D). Immediately after returning for ICPD, the National Steering Committee for the future challenges met and reviewed their action plans. The next month a National Committee for the Implementation of the Programme of Action was constituted. Over the coming months, these two initiatives would come together and the result would be the development of a National Plan of Action. This was a new type of plan that was theme-based and cut across different sectors. Its emphasis is on human development and concentrates on achieving improvement in the quality of life. It has time-bound goals on mortality, education and reproductive health, as well as attaining gender equity, equality and women's empowerment as the key to improving the quality of life for all society.

The MCH Coordination Cell of the Directorate of Family Planning undertook another activity immediately post-ICPD when they began to plan the safe motherhood meeting for December. The Cell received significant assistance from delegates who had been in ICPD to develop the agenda and the papers to be presented. The opportunity to educate the Prime Minister was not lost. Six hundred attended the first day of the safe motherhood meeting where Dr. Nafis Sadik gave the key note address. Dr. Sadik praised the success of the program in Bangladesh and its excellent inclusion of all 
stakeholders in its program. She emphasized the progress Bangladesh had made in education and the economic security of women. She brought out the ICPD agenda by reminding the conference participants that the "empowerment of women will be the key...Cairo drew attention to the emerging global consensus that the promotion of women's rights, security and dignity should be at the center of population activities and high on the agenda of all governments, political organizations and NGOs, as well as commercial and industrial enterprises, as part of their core strategy for development." She concluded by emphasizing the "leading and exemplary part" Bangladesh would play. "Evidence of the continuing success of your national family planning program greatly encouraged us as we worked towards the success of Cairo. Your sustained momentum towards reproductive health and safe motherhood in the coming years will demonstrate that investment in equity and equality for women pay excellent dividends in the form of balanced and peaceful development."

It was fortuitous that this high-level meeting planning was underway prior to the delegation leaving Cairo for shortly after returning, the Secretary of the MOHFW retired. However, the new Secretary took up the follow-up on ICPD.

Following the December Safe Motherhood conference, meetings on post-ICPD continued. In January the first meting of the National Committee for Implementation of ICPD was held. The meeting resulted in the formation of task forces, which would review Chapters XIII, XIV and XVI of the program of action and to review and compare the national documents with ICPD Programme of Action. These two tasks generated several other meetings.

However, the next watershed event was the Paris meeting between Bangladesh and its development partners in population and health. This high level meeting determined the future course of the program by agreeing that services needed to be delivered by an integrated staff of health and family planning workers who would provide a basic package of services. The important elements included: one-stop shopping for the convenience of customers; a delivery system which was cost efficient; and high quality services which went beyond family planning. This motivation for planning to provide this package was two-fold: (i) policy makers and development partners were determined to set a course which would reduce maternal mortality; and, (ii) it was essential to address the inefficiencies of two separate systems delivering services.

Returning from Paris with the basic services package in mind, the MOHFW constituted a Technical Review Committee and a Task Force which prepared a new strategy document: 'Strategic Directions for the Bangladesh National Family Planning Program: 1995-2005'. This strategy was based on a client-oriented approach and proposed to: expand the program to serve couples who intend to use family planning services, and improve the quality of services so that more clients use appropriate methods correctly and continually. The strategic vision assumes that the program should achieve the following goals in the next ten years: increase access to family planning services to those who have an unmet need for contraception; improve the quality of family planning services so that all users continue using methods effectively without dropping out; enhance male participation in family planning; revitalize the use of long-term methods; 
improve the long-term financial sustainability of the program; and reach the replacement level of fertility to expedite the population stabilization process. Even though this strategy was developed post-ICPD, the emphasis was on family planning. However, as the design processes got underway for future program assistance, the shift to a reproductive health agenda began to crystallize.

USAID began developing its program of assistance that would begin in 1997 and continue for seven years. Like the other development partners, USAID used a consultative approach for its program design. To ensure that all voices were heard, USAID implemented a customer survey as part of the design process. From their potential customers they learned, among other things, that 'one-stop shopping' for health services was valued, and customers were willing to contribute to the cost of services through payment of fees. USAID assistance would be provided mainly through cooperating agencies and NGOs. However, they included the government and development partners in their planning. Many of the key informants commented on this revolutionary step for USAID who had previously planned their programs in isolation from those who were not directly funded by them.

The result of a one-year design process was the National Integrated Population and Health Program (NIPHP) which was officially launched in October 1997. This program reflects the national initiatives, giving primary emphasis on enhancing "...the quality of life of poor and underprivileged members of society by helping to reduce fertility and improve family health." This will be accomplished with the following program actions: delivering a essential package of high quality, high impact services to the areas of greatest need; promoting awareness and use of those services through a variety of information, education and communications to protect and provide for their own health; enhancing the ability of individuals, families, and communities to protect and provide for their own health; building a strong NIPHP organization and supporting systems to maximize integration of services to clients and coordination among the partners; promoting sustainability throughout the delivery chain; and encouraging the government to develop and implement a policy framework that facilitates and mobilizes government and non-government resources in support of NIPHP to the community level.

During this same period, the MOHFW began the long-road which culminated in a new strategy document. Like USAID, the MOHFW followed a consultative process. The Health and Population Sector Strategy (HPSS) is described in the Programme Implementation Plan (1998) in this way:

The Health and Population Sector Strategy (HPSS) was formulated in consultation with development partners and stakeholders to reform the health and population sector to provide a package of essential health care services for the people of Bangladesh and to slow population growth. The services should be responsive to clients' needs - especially those of children, women and the poor, and achieve quality of care with adequate delivery capacity and financial sustainability....The main sectoral objectives of the HPSS are: maintenance of the momentum of efforts in Bangladesh to lower fertility and reduce mortality; reduction of maternal mortality and morbidity; and reduction in the burden of communicable diseases. ...The Essential Services Package identified in the HPSS consists of basic reproductive and 
child health services, including family planning, maternal care and immunization as well as control of selected communicable diseases, limited curative care and behavior change communication. The ESP will be delivered through different levels of the primary health care system (Community, union, thana and district levels).

The HPSS calls for clients to receive an essential package of services in one location. The HPSS vision is to be responsive to clients' needs, to provide better quality services, to become financially sustainable, and to develop adequate service capacity. To deliver on this vision, the MOHFW plans sweeping changes in the management of the program. These changes are based on the realization that a vertical service delivery structure did not adequately respond to the needs of clients and limited the potential for increasing the range, quality and effectiveness of services. There were recognized problems of linkage between projects and poor institutional coordination and support within the sector. The separate health and family planning structures impeded referrals, generated internal conflicts, and contributed to the low utilization of public facilities. While these management problems had been previously identified, the vision and will to change the system had been lacking. One of the greatest contributions of the strategy process was the combined strength of all stakeholders to take on the challenge of revising the management system.

The sectoral objectives of HPSS still reflect the importance of containing population growth. However, this does not stand in isolation but is supported by other equally strong objectives. These are: maintenance of the momentum of efforts to lower fertility and mortality; reduction of maternal mortality and morbidity; and reduction of the burden of communicable diseases. Achieving these objectives required the identification of several basic strategies. Foremost among these is the identification of the elements of the essential package of services (EPS). The package includes: basic reproductive health and child health services, including family planning, maternal care and immunization as well as control of communicable diseases, limited curative care and behavior change communications. The EPS will be delivered through different levels of the primary health care system (community, union, thana and district). To implement the HPSS a sector-wide management (SWM) approach has been adopted. This is intended to improve the performance of the health sector and enhance efficiency.

The HPSS formed the basis for discussion and design of the fifth project for population and health assistance from the consortium of development partners led by the World Bank. The result is the Health and Population Sector Programme (HPSP) 1998-2003. Based on the essential package of services, the goals of the program are first, to reduce mortality of mothers, infants and children under-five. The second primary goal is to reduce unwanted fertility. To achieve these objectives, the MOHFW will implement a plan of integration of services beginning with reorganization and restructuring at the thana level and below. HPSP was approved in July 1998 and implementation is underway. 


\section{Policy Changes}

There have been several policy changes already in place or in process in this decade in Bangladesh. (Appendix E). A National Population Policy Committee is currently developing a new population policy, which will be based on the National Plan of Action. This policy is expected to be completed in mid 1999 and will reflect a shift from the demographic approach to controlling population growth to one which focuses on the individual needs of couples for access to high quality services to meet their needs for family planning services.

There is a new National Food and Nutrition Policy which stresses the needs of vulnerable groups: infants, young children, women (adolescent girls, pregnant and nursing mothers) and the elderly. The objectives are to: increase production and availability of both staple and non-staple nutritious food, minimize post-harvest losses, develop food preservation and distribution technologies; improve the health and nutritional status of the people, especially of children, women and the elderly; consider the importance of the family unit to provide adequate physical, mental, emotional and social needs of children and other vulnerable groups, including the elderly; to ensure safe drinking water, arrange for proper disposal of wage, improve sanitation and environmental hygiene at personal and community level; provide formal and nonformal nutrition education to the people especially women and children; and undertake all measures to increase income generating activities for poverty alleviation particularly for women in rural households.

The National Children's Policy was adopted after 1994. Six main goals have been identified to guarantee the rights of children: ensure the right of survival after birth with the provision of health, nutrition and physical security; ensure proper facilities for education; improve family health; extend special assistance to those in difficult circumstances; ensure the best interests of the children through legal rights within the national, social and family context.

The National HIV/AIDS and STD Policy was adopted in 1996. The policy provides comprehensive guidelines on: HIV/AIDS Epidemiological Surveillance; HIV testing policy; management of AIDS and HIV infections; counseling of HIV/AIDS clients and confidentiality; national blood transfusion services; HIV/AIDS/STDs and the impact on all sectors of society - women, men, children, adolescents; ethical aspects of HIV/AIDS research, and the legal aspects of HIV/AIDS.

There is a policy document on Safe Blood Transfusion. The government is responsible for the establishment of a nationally controlled and coordinated blood transfusion service and maintenance of self-sufficiency for blood and blood products. The government endorsed the Code of Ethics for Blood Donations and Transfusions approved by International Society for Blood Transfusion (ISBT) and WHO (1980).

The policy adopted in Bangladesh for women's development is largely influenced by the resolution $3520(X X X)$ of the United Nations General Assembly. The government of 
Bangladesh acknowledged that equal participation of women is necessary for overall development of the nation.

The Bangladesh National Women Development Policy was adopted in March 8, 1997. This policy document, first of its kind in Bangladesh, delineates government's firm commitment on 14 broad areas - implementation of the human rights and fundamental freedom of women; elimination of all discrepancy against girl child and enactment of relevant laws; elimination of all forms of violence against women; armedrace, war and women; education and training; sports and culture; ensure active and equal participation of women in all spheres national economy; eradication poverty among women; economic empowerment of women; job opportunity for women; other secondary assistance and services; women and technology; food security for women; political empowerment of women; administrative empowerment of women; health and nutrition; housing and shelter; women and environment; women and mass media; specific distress and disadvantaged women.

\section{Government-NGO-Private Sector Collaboration}

As is clear throughout this elaboration of the ICPD process, the government has always worked with NGOs to promote various social programs in Bangladesh. The ICPD PoA did not influence this partnership. In fact, the reverse is more likely to be true. The successful collaboration of government and NGOs in the family planning program and in other development activities is exemplary and often cited as a contributing reason for the success of development efforts. This example could have influenced the inclusion of the importance of partnerships in the PoA.

Bangladesh is an excellent case of government-civil society, government-NGO collaboration. A total of 956 NGOs are in operation in Bangladesh: 781 NGOs in micro credit, education, sanitation and nutrition improvement programs, and 175 in family planning. The development NGOs currently work in about 78 percent of the villages and about 24 million people benefit from their activities. The NGOs have greatly expanded access to micro-credit and small scale income generation facilities for rural women. More than 400 NGOs including Grameen Bank are involved in micro-credit program and a total of over eight million beneficiaries 80 percent are famale received small loans from them. The government has involved 14 NGOs to implement non-formal education programs, 325 NGOs are involved in literacy programs. Most of these NGOs have programs for mass and adult education.

Currently, BRAC is involved in implementing Bangladesh Integrated Nutrition Project in six thanas. The Government has a plan to expand this through several other NGOs. Helen Keller started a home gardening/nutrition education project through NGOs to reach at least 90 of the 470 thanas and increase production of vitamin A sources by local production of vegetables throughout the year.

A network of 175 NGOs provide approximately one-fourth of the country's overall family planning services. NGOs providing FP-MCH services cover one-fifth of the 
country's population. The contraceptive use rate in the NGO served areas has increased from 19.5 percent to 58 percent during the last 15 years. NGO performance in both urban and rural areas contributed significantly to the national achievements. It is estimated that about 25 percent of overall national achievement of CPR and 35 percent of sterilization acceptors is attributable to NGOs. The expanded program on immunization (EPI) activities in the urban areas are operationally well-integrated with family planning service delivery through the major involvement of the NGOs. Development NGOs also make indirect contribution to child survival. NGOs have been instrumental in bringing about positive changes in health and quality-of-life indicators such as immunization, maternal and child health, and family planning.

To improve reproductive health status of the women, NGOs have, since 1994, begun integrating RTI services to expand the range of reproductive health services. The NGOs have introduced RTI screening, diagnosis and treatment by following WHO approved strategy called 'Syndromic Management of RTI'. NGOs are giving special attention to postpartum women for breast feeding, postpartum check-up, and counseling for contraceptive acceptance within six weeks to six months of their deliveries.

NGOs have been key in pushing the program forward and influencing the national policy. The quality assurance system initiated by the NGOs has been adopted and used in the government system. They were instrumental in enhancing government capability by developing training and counseling curricula including client-centered, life-cyclebased counseling, methodology and materials, training government physicians on NSV, paramedics, and counselors. NGOs conducted training for managers and senior technical staff to develop a core team of trainers and provided technical assistance to the trainers in training service providers on delivery of injectable, counseling, proper waste disposal, infection prevention, side-effect management and complications. NGOs introduced home and cluster-based injectable service delivery.

The strong role NGOs play in the Bangladesh family planning and $\mathrm{MCH}$ Program is possible because of the government support to the NGO sector. In order to be responsive to facilitate NGOs' utilization of foreign funds, the government has had to be innovative in its approach to NGO management. NGOs themselves are stakeholders, largely represent civil society, and are well linked with the local community. NGOs have made significant contributions in decentralizing responsibility and implementation of family planning to the community level. Where NGOs make the effort to be advocates, they are highly successful at involving their communities in supporting MCH-FP efforts.

Family planning is the first program to employ women in the rural areas. More than 23,000 government family planning workers, three-fourths of 13,000 FP NGO workers, and 80 percent of 100,000 development workers are female. The impact on social attitudes toward women has perhaps been the most far-reaching of NGO contributions. NGO activities have led to a noteworthy female entry into income earning process and have concretely strengthened female mobility - both physical, economic and social. This in turn has demonstrated the potential of women as powerful social and economic change agents. 
NGOs future role is to implement the NIPHP which is fully consistent with and its cornerstone ESP that fosters active participation from all family members (men, women and children). The package covers family planning, priority child and maternal health, STIs/HIV/AIDS.

The NGOs challenge is to maintain and build on the successes achieved on pioneering work done in the past. The NGOs will increase accessibility and utilization of highquality, high impact affordable ESP, which is more comprehensive than the previously narrowly-focused family planning and will be delivered through 'one stop shopping'. In order to maximize the quality of services, both government and NGO service providers will be trained in ESP service delivery and management.

Embracing the HPSS, the NGOs are trying to take the lead in implementing a shift in service delivery design from field worker-based door step delivery to static service delivery points in a phased manner using a tiered approach; and from routine home visits to planned and targeted home visits as necessary. The NGO will focus on lowperforming geographic areas and undeserved demographic segment. The most important role the NGOs will play is to sensitize individual families, couples, women and men in proactively seeking clinic-based services, demanding quality and sharing the cost of those services.

The mandate to coordinate NGO activities is by and large assigned to two institutions: the NGO Affairs Bureau (NGOAB) on behalf of the Government and the Association of Development Agencies in Bangladesh (ADAB) of behalf of the NGOs. In addition, the recently constituted Government-NGO Consultative Council (GNCC) is welcome for its potential to bring forth real possibilities of increased collaboration between the government and the NGOs.

Until 1990, the Bangladeshi NGOs were subjected to complex set of rules and procedures by which Government regulated their operations. The NGOs were required to apply to different Government agencies for registration, project approval and permission to obtain foreign funds. Cumbersome bureaucratic procedures not only increased paper work for the NGOs, but also resulted in the loss of substantial funds due to inordinate delays in the process. The 1980's witnessed a huge backlog of projects pending the government approval. Seeing the need for a one-stop service the government created the NGOAB under the Prime Minister's Secretariat in 1990. Since then the government has assigned NGOAB all responsibilities to coordinate NGOs under the 1978 Foreign Donations (Voluntary Activities) Regulation Ordinance and the 1982 Foreign Contribution (Regulation) Ordinance. The establishment of the NGOAB has produced significant improvement from the past. It enables the NGOs to obtain their registration clearance, approval and permission through a single agency of the government within a specified timeframe. The government has also revised procedures in order to expedite permissions for NGOs to access foreign funds and get their projects approved.

NGOs are linked through a variety of mechanisms. The largest coordination body for these NGOs in Bangladesh is ADAB. Its mandate and membership composition make it a key organization to contribute towards a healthier government-NGO relationship. 
ADAB is a registered NGO that was set up in 1974 as a forum for international NGOs. It has now grown into a membership organization for more than 750 NGOs representing a whole spectrum of international and local NGOs. Membership in ADAB is voluntary. Local NGOs are organized under chapter networks located in 16 greater districts of the country. Identification of small NGOs and the subsequent need-based support to them are delivered through formation of chapters. These networks have been acknowledged as one of the significant achievements of ADAB. As an umbrella of the NGOs, ADAB has several key functions to perform. Besides coordinating activities of its members it provides technical and advocacy support to small NGOs.

Besides their membership in ADAB, many NGOs in Bangladesh have clustered and grouped around particular themes. The oldest ones of these include Voluntary Health Services Society (VHSS) and NGO Forum for Drinking Water and Sanitation (NGOFDWS). During the last five years, such networks have been set up to represent almost the full range of NGO activities (e.g. micro-credit, environment, land settlement, craft export, women's issues, disaster management, child rights, literacy etc.).

The recently constituted Government-NGO Consultative Council is a very positive and timely initiative with great potentials for improving government-NGO relations.

\section{Conclusions}

The evidence gathered during this review process indicates that radical changes occurring in the family planning and health service programs in Bangladesh are not the result of ICPD. However the changes now being implemented do parallel the Programme of Action guidelines. This should not be a surprising finding. Like many mature family planning and $\mathrm{MCH}$ programs, the Bangladesh one had reached a plateau in the latter part of the eighties decade. All the easy to reach communities and individuals had received services. What remained were those who needed either more information, more convenient services, or a different kind of impetus to encourage their participation in any of the family planning or $\mathrm{MCH}$ services which were being provided by both government and NGO programs. The decisions to revamp existing programs by looking at unmet need approaches for family planning, increasing the quality and outreach of all services, developing programs for specific under-served populations, and combining more services together were in place before the first PrepCom meeting.

ICPD did provide encouragement to the on-going process in the family planning and health sectors, particularly since the same individuals in the delegations leading were involved in leading the change process at home. It also encouraged a pro-active involvement of other sectors. Though the family planning program has always been one which involved other sectors, coordination has been greatly strengthened since ICPD. Also strengthened is the recognition of the importance of all development sectors to achieve family planning and health, particularly maternal health, goals. 
Setting appropriate policies has not been a problem for Bangladesh at any time in its history. The family planning program has always been based on a two-pronged approach with the control of population growth and improvement of maternal and child health as equal concerns. The improvement in the status of women and girls has also been a constant policy concern. It is rather in the implementation of appropriate policies where Bangladesh has had difficulties in the past and could again in the future. Thus, in the past and in spite of an equal concern for population growth and maternal health, there has often been an emphasis on contraceptive acceptance rather than a holistic approach to women's health. Targets for family planning achievements have too often been the emphasis of the program.

The post-ICPD era has potential risks, as well since the change process which Bangladesh has embarked upon is extremely difficult. In order to provide one-stop shopping for the essential package of services proposed, major changes will have to occur in the management of both the health and family planning programs. These changes require thorough reforms at all levels - but particularly at the primary care level where most services are being provided. Training and restraining of service providers is also a critical element. All primary health care workers, from both family planning and health cadres, are constrained by their lack of basic training in the new services to be delivered. This reform will be the starting point for the government's program, with support from the World Bank led consortium of donors. It is just beginning now. Before it can be fully materialized, the planned restructuring of the services must be implemented. Whether it will succeed is not a matter of policy - since the policies are clearly in favor of this new system and the services - but is a matter of implementation. Since the process is only beginning it is impossible to predict the end result. As in the past, however, the will to provide services in a difficult environment is strong. This will has carried the Bangladesh program through many difficult periods in the past.

Finally, while ICPD was not a primary influence on the new directions of the Bangladesh program, the forums which led to it and have followed since, have been useful. These are afforded an opportunity to share the Bangladesh experience - its success in improving the health of women and children in a resource poor environment; its multi sectoral approach to improving the status of women; and its effective use of NGOs in all levels of the program. Perhaps the greatest influence of international conferences is not in the documentation produced, even when it is as comprehensive as the Programme of Action of ICPD, but rather in the opportunity these afford for countries - and individuals in delegations - to listen and learn from one another. 


\section{References}

Akhter, H. H. 1998. Implementing the ICPD Program of Action: Bangladesh Experience. Paper presented at the International Conference on Reproductive Health, Mumbai, India.

Akther, H. H., M. H. Rahman and S. Ahmed. 1996. Reproductive Health Issues and Implementation Strategies in Bangladesh. Dhaka: BIRPERHT.

Akther, H. H., N. Huq and M. A. Rouf. 1996. Health Sector Review Based on the Recommendations of the Platform for Action of the 4th World Conference on Women. Dhaka.

Alauddin, M. and A. Rouf. 1995. ICPD and Bangladesh Vision of GO-NGO Collaboration: The National FP/MCH Program in Bangladesh. Paper Presented at the Workshop on Success of Government-NGO Collaboration in Population and Development in Bangladesh, Dhaka.

Anwar, M. T. and N. Kabir. 1998. Situation Analysis of HIV/AIDS BCC in Bangladesh. Dhaka.

Bangladesh Population and Health Consortium and University Research Corporation. 1997. Role of NGOs in Provision of Safe Motherhood. Dhaka.

Bangladesh Population and Health Consortium. 1998. Government-NGO Collaboration and Policy Dialogue in Health and Family Planning: Lessons Learned by the BPHC NGO Project. Dhaka.

BRAC. 1997. Reproductive Health and Disease Control Program, Annual Report. Dhaka.

BRAC. 1998. Implementing Women's Health programs in the Community: Bangladesh Experience. Dhaka.

BRAC. 1997. Non Formal Primary Education (NFPE), Annual Report. Dhaka.

Barkat, A. 1998. Governance of Public Health in Bangladesh. In Crisis in Governance: A Review of Bangladesh's Development 1997. Dhaka: Center for Policy Dialogue and University Press Limited.

Barkat, A., M. Majid, S. Akhter and S. Hossain. 1998. Maternal Mortality and Morbidity in Bangladesh: Situation Analysis, Lessons Learned and Future Strategies. Dhaka.

Barkat, A., S. H. Khan and N. N. Ratna. 1997. Family Planning Program in Bangladesh: Success and Challenges. Dhaka. 
Barkat A., M. A. Uddin and M. Hossain. 1998. "Bangladesh Country Report: Implementation of ICPD Programme of Action and the Bali Declaration on Population and Sustainable Development", Presented at ESCAP High Level Meeting, Bangkok, Thailand.

Barkat. A., S. R. Howlader, B. Khuda, J. Ross and M. L. Bose. 1997. Family Planning Unmet Need in Bangladesh: Shaping of a Client-Oriented Strategy, The Futures Group International, Inc., USA and University Research Corporation (Bangladesh), Dhaka.

Barkat, A. 1997. "Population Distribution, Urbanization and Internal Migration in Bangladesh", in A. Barkat and S.R. Howlader (eds) Population and Development Issues in Bangladesh, Ministry of Health and Family Welfare, Government of Bangladesh, Dhaka.

Blood Transfusion Sub-committee and National AIDS Committee. 1997. Plan of Action on Safe Blood Transfusion. Dhaka.

Choudhury, A. Y. 1998. Partnership Among the Government, NGO, Private Sector and International Community in the Area of Reproductive Health. Paper presented at the ICPD+5 Round Table on Partnership with Civil Society, Dhaka.

Finkle, J. L. and B. Crane. 1975. The Politics of Bucharest: Population, Development, and the New International Economic Order. Population and Development Review 1, 1:87-114.

Finkle, J. L. and B. Crane. 1985. Ideology and Politics at Mexico City: The United States at the 1984 International Conference on Population. Population and Development Review 11, 1:1-28.

Hardee, K., K. Agarwal, N. Luke, E. Wilson, M. Pendzich, M. Farrell and H. Cross. 1998. Post-Cairo Reproductive Health Polices and Programs: A Comparative Study of Eight Countries. Washington, DC: The futures Group International, Research Triangle Institute and The Centre for Development and Population Activities.

Khan, M. M. and R. A. Yoder. 1998. Expanded Program on Immunization in Bangladesh: Cost, Cost-effectiveness, and Financing Estimates. Dhaka: ICDDR, B and Abt Associates Inc.

Khuda. B., and A. Barkat. 1994. The Bangladesh Family Planning Program: Key Programmatic Challenges and Priority Action Areas Prepared for the International Conference on Population and Development (ICPD), Cairo, September 1994, National Advisory Board, Dhaka.

Khuda, Barkat-e, A. Barkat, J. Helali, P. Miller and J. Haaga. 1994. Population Policy in Bangladesh: A Review of Ten Priority Areas. Dhaka: University Research Corporation and Population Council. 
Khuda B., T. H. Kane and J. F. Phillips. 1997. Improving the Bangladesh Health and Family Planning Programme: Lessons Learned Through Operations Research, International Center for Diarrhoeal Diseases Research, Bangladesh, Dhaka.

McIntosh, C. A. and J. L. Finkle. 1995. The Cairo Conference on Population and Development: A New Paradigm. Population and Development Review 21, 2:223260.

Ministry of Health and Family Welfare. 1994. Future Challenges in the FP-MCH Program: A Plan For Action. Dhaka.

Ministry of Health and Family Welfare. 1996. Bangladesh Family Planning Program: Achievements and Challenges. Dhaka.

Ministry of Health and Family Welfare. 1997. Bangladesh National Food and Nutrition Policy 1997. Dhaka.

Ministry of Health and Family Welfare. 1997. Bangladesh National Plan of Action for Nutrition. Dhaka.

Ministry of Health and Family Welfare. 1998. Fifth Health and Population Programme 1998-2003. Program Implementation Plan. Dhaka.

Ministry of Health and Family Welfare. 1993. The National FP-MCH IEC Strategy for Bangladesh 1993-2000. Dhaka.

Ministry of Health and Family Welfare. 1996. Balancing Future Resources and Expenditures in the GOB Health and Population Sectors. Working Paper No.3. Dhaka.

Ministry of Health and Family Welfare. 1996. Strategic Directions for the Bangladesh National Family Planning Program 1995-20005. Dhaka.

Ministry of Health and Family Welfare. 1996. National Policy on HIV/AIDS and STD Related Issues. Dhaka.

Ministry of Health and Family Welfare. 1996. Report of the National Workshop on Reproductive Health with Gender Perspective. Dhaka.

Ministry of Health and Family Welfare. 1997. Health and Population Sector Strategy (HPSS). Dhaka.

Ministry of Health and Family Welfare. 1997. National Reproductive Health Strategy. Dhaka. 
Ministry of Health and Family Welfare. 1997. Population and Development Issues in Bangladesh, National Plan of Action Based on ICPD 1994 Recommendations. Eds. A. Barkat and S. R. Howlader. Dhaka: Bangladesh Progressive Enterprise Press Limited.

Ministry of Health and Family Welfare. 1998. Population and Development Challenges in Bangladesh: Innovations and Scopes for Collaboration. Country Report Presented at the Fourth Annual Board Meeting of the Partners in Population and Development, Cairo, 7-11 November.

Ministry of Health and Family Welfare. 1998. Adolescent=s Health and Development: Issues and Strategies: Empowering Adolescent Girls for Sustainable Human Development. Country Report Presented at the 1998 South Asia Conference on Adolescents, New Delhi, 21-23 July.

Ministry of Health and Family Welfare. 1998. Health and Population Sector Programme 1998-2003. Programme Implementation Plan (Part-I). Dhaka.

Ministry of Health and Family Welfare. 1998. Health and Population Sector Programme 1998-2003. Programme Implementation Plan (Part-II). Dhaka.

Ministry of Women and Children Affairs. 1996. Fourth World Conference on Women: Declaration and Program of Action. Dhaka.

Ministry of Women and Children Affairs. 1997. National Action Plan for Women=s Advancement: Implementation of the Beijing Platform for Action. Dhaka.

Ministry of Women and Children Affairs. 1997. National Women=s Development Policy. Dhaka.

Ministry of Women and Children Affairs. 1994. National Children Policy. Dhaka.

Ministry of Women and Children Affairs. 1997. Combined Third and Fourth Periodic Report in Accordance with Article 18 of the Convention on the Elimination of all Forms of Discrimination against Women. Dhaka.

Ministry of Planning. 1995. Participatory Perspective Plan for Bangladesh 1995-2010. Dhaka.

NIPORT, GTZ and Population Council. 1995. Proceedings: Workshop on Research Priorities in Population \& Reproductive Health. Dhaka.

Pathfinder International. 1995. Grassroots Perspective on Future Challenges in FP-MCH Program: An Integrated Report on Seven Thana Level Workshops. Dhaka.

Pathfinder International. 1995. Sustainability of the FP-MCH Program of NGOs in Bangladesh: Future Search Workshop. Dhaka. 
Pendzich, M. 1998. Reproductive Health-Case Study: Bangladesh. Country Reports. Washington, DC: The Future Group International, Research Triangle Institute and the Centre for Development and Population Activities.

Planning Commission, Ministry of Planning. 1998. The Fifth Five Year Plan 1997-2002. Dhaka.

Ross, J. L. et al. 1995. Health, Gender and Sexuality: Bangladesh Country Report. Prepared for the Asia and Pacific Regional Network on Gender, Sexuality and Reproductive Health. Manila, Phillipines.

Singh, J. S. 1998. Creating a New Consensus on Population. London: Earthscan Publications Ltd.

United Nations Population Fund. 1995. Strengthening MCH/FP Services at MCWCs in Bangladesh. Dhaka: United Nations Population Fund.

United Nations Population Fund. 1996. Clinical Contraception Services: Revitalization and Renewal. Dhaka: United Nations Population Fund.

United Nations Population Fund. 1996. Reproductive Health and Gender. Dhaka: United Nations Population Fund.

United Nations Population Fund. 1996. Reproductive Health in Bangladesh: A Sectoral Review. Dhaka: United Nations Population Fund.

United Nations Population Fund. 1996. Workshop Report: Collaboration between Government and Non-government Organizations in Population and Development in Bangladesh. Dhaka: United Nations Population Fund.

United Nations Population Fund. 1997. The Right to Choose: Reproductive Right and Reproductive Health. New York: United Nations Population Fund.

United Nations. 1995. Programme of Action Adopted at the ICPD, Cairo, 5-13 September. New York: United Nations.

USAID. 1998. National Integrated Population and Health Program: Results Package 19972004. Dhaka.

World Bank. 1996. Pursuing Common Goals: Strengthening Relations between Government and Development NGOs. Dhaka: University Press Limited. 


\section{Appendix $A$}

\section{List of Persons Contacted}

\section{Name}

1. Syed Shamem Ahsan

2. Dr. Abu Jamil Faisel

3. J. S. Kang

4. Faruk Ahmed

5. Azizul Karim

6. Dr. Ahmed Al-Kabir

7. Dr. M.A. Mabud

8. Dr. Jahiruddin Ahmed

9. Dr. Halida Hanum Akhter

10. Dr. Alain P. Mouchiroud

11. Mufaweza Khan

12. Professor Barkat-e-Khuda

13. Margaret A. Neuse

14. Richard Green

15. Dr. Zareen Khair

\section{Designation}

Senior Policy Advisor, NIPHP

Chief of Party

AVSC International

Senior Population Specialist

World Bank

Population Specialist

World Bank

Joint Chief

Ministry of Livestock \& Fisheries

Deputy Chief of Party

Urban Family Health Partnership

Divisional Chief, Agricultural Division

Ministry of Finance

Director MCH Services \& Line Director (ESP)

Directorate of Family Planning

Director, BIRPEHRT

UNFPA Representative

UNFPA

Executive Director

Concerned Women for Family Planning

Chief of Party, ORP

ICDDR,B, Bangladesh

Team Leader

Population \& Health Team

USAID, Dhaka

Deputy Team Leader

Population \& Health Team, USAID, Dhaka

Project Management Specialist

Population \& Health Team

USAID, Dhaka 


\section{Appendix $\boldsymbol{B}$}

\section{Guideline for Discussion with the Key Personnel on Achievement of Bangladesh National Program since the ICPD'94: POLICY AND PROGRAM LEVEL CHANGES}

\section{A. General Information}

1. Name of the person discussed with :

2. Current designation and work place :

3. Designation and work place at the time of Cairo Conference

4. Duration of services in the Population/Health sector: From: To:

B. Talking issues related to ICPD impact

1. How and to what extent were you involved in the following:

\begin{tabular}{|l|l|l||}
\hline & How & $\begin{array}{c}\text { To what extent } \\
\text { (greatly/medium/low) }\end{array}$ \\
\hline $\begin{array}{l}\text { During the period of } \\
\text { preparatory activities for Cairo } \\
\text { Conference }\end{array}$ & & \\
\hline In the Cairo Conference & & \\
\hline In the activities after Cairo & & \\
\hline
\end{tabular}

2. The main area(s) of activities related to ICPD proposals/PoA you were/ are involved in:

3. What changes have been brought about at the policy level in the national program/areas of your activities after Cairo Conference? Please substantiate, if possible.

4. How much of the changes at the policy level is due to Cairo Conference? (Acceleration of the process of change will also be considered as contribution of CAIRO). Please explain why.

5. How were the changes made at policy level? (Explain the process and substantiate). 
6. What preparatory activities have been done/measures taken to implement the policies? (Please substantiate).

7. Has implementation of policies started at field level? (If yes) since when and how much (in terms of program areas/components, level, coverage and magnitude)? Give details of implementation plan.

8. What is the outcome of implementation?

9. Are there any problems in implementation at field level?

10. Are any measures being devised to resolve those problems? What are those?

11. Are there any activity/activities (program component) which have started long before ICPD and still continuing but have been reinforced and accelerated after Cairo Conference? What are those? Why do you think so? 


\section{Appendix $C$}

\section{List of Bangladeshi Delegates Attending ICPD'94}

Mr. Chowdhury Kamal Ibne Yusuf

Hon'ble Minister for Health and Family Welfare

Government of People's Republic of Bangladesh

Mr. Syed Shamim Ahsan

Secretary

Ministry of Health \& Family Welfare

Mr. Reaz Rahman

Permanent Representative of Bangladesh to United Nations

Mr. Tufail K. Haider

Ambassador of Bangladesh in Egypt

Mr. M. Fazlur Rahman

Additional Secretary

Ministry of Health \& Family Welfare

Mr. M. A. Shaheed

Joint Secretary

Ministry of Health \& Family Welfare

Mr. Md. Azizul Karim

Joint Chief (Planning)

Ministry of Health \& Family Welfare

Mr. Mr. Khairuzzaman Chowdhury

Director General

Directorate of Family Planning

Mr. Md. Abidur Rahman

Senior Assistant Secretary

Ministry of Health \& Family Welfare

Ms. Ayesha Shirin Rahman

Additional Director

Directorate of Women Affairs

Dr. M. Aminul Islam

Director (MCH/FP)

Directorate of Family Planning 


\author{
Mr. Tofayel Ahmed \\ Deputy Director \\ Directorate of Family Planning \\ Dr. Shamim Ahmed \\ Associate Professor \\ Institute of Post Graduate Medicine and Research \\ Prof. Damessie Habte \\ Director \\ International Center for Diarrhoeal Disease Research, Bangladesh
}

\author{
Mr. Alamgir M. A. Kabir \\ President \\ Family Planning Association of Bangladesh \\ Mr. Fazle Hasan Abed \\ Executive Director \\ Bangladesh Rural Advancement Committee \\ Dr. Monowar Hossain \\ Executive Director \\ Multi Disciplinary Action Research Center
}

Mr. M. A. Rouf

Chief Executive

Family Planning Services and Training Center

Dr. Halida Hanum Akhter

Director

BIRPERHT

Mrs. Mufaweza Khan

Executive Director

Concerned Women for Family Planning

Mrs. Rokhsana Khondaker

Executive Director

Khan Foundation

Ms. Sandra Kabir

Executive Director

Bangladesh Women's Health Coalition

Ms. Nasreen Huq

Member

Naripakha 
Mr. Mukarram Hushen Chowdhury

Deputy Program Director

Family Planning Management \& Development

Mr. Abu Yusuf Chowdhury

Executive Director

PIACT, Bangladesh

Dr. Muhammed Alauddin

Country Representative

The Pathfinder International, Bangladesh

Dr. Barkat-e-Khuda

Project director

International Center for Diarrhoeal Disease Research, Bangladesh

Begum Nur Nahar Islam

Executive Director

Jatiya Mohila Sangstha 


\section{Appendix D}

Chronology of Major Events in Bangladesh both Pre and Post-ICPD'94

\begin{tabular}{||l|l||}
\hline \multicolumn{1}{||c||}{ Date } & \multicolumn{1}{c||}{ Events } \\
\hline \multicolumn{2}{|c||}{ Pre-ICPD } \\
\hline September, 1993 & $\begin{array}{l}\text { Publication and approval of the National FP-MCH IEC strategy (1993-2000) } \\
\text { by MOHFW. }\end{array}$ \\
\hline November, 1993 & $\begin{array}{l}\text { MOHFW initiated dialogue with civil society to identify future challenges } \\
\text { and to develop time-bound Action Plan. Task forces and expert committees } \\
\text { were constituted to identify program gaps and suggest action alternatives. }\end{array}$ \\
\hline June, 1994 & $\begin{array}{l}\text { Formulation of "Plan of Action" which identified 9 immediate priority action } \\
\text { areas. }\end{array}$ \\
\hline December, 1993 & Outcome of the above shared in "National FP Fortnight". \\
\hline
\end{tabular}

Post-ICPD

\begin{tabular}{|l|l|}
\hline September, 1994 & International Conference on Population \& Development, Cairo.
\end{tabular}

\begin{tabular}{|l|l|}
\hline October, 1994 & Briefing meeting on ICPD '94 by NGO-CC. \\
\hline
\end{tabular}

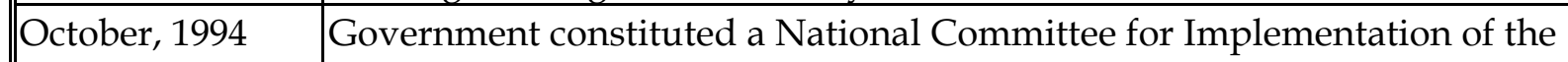

Program of Action of the United Nations ICPD recommendations.

\begin{tabular}{|l|l|}
\hline December, 1994 & Safe Motherhood Conference.
\end{tabular}

\begin{tabular}{|l|l|}
\hline January, 1995 - & Series of meetings of the National Committee for Implementation of ICPD.
\end{tabular}

August, 1996

\begin{tabular}{|l|l}
\hline February, 1995 & Formation of ICPD Task Force.
\end{tabular}

February, 1995 MOHFW circulated copies of the PoA of ICPD to the member secretaries of nine working groups of NSC and requested comments and suggestions.

\begin{tabular}{|l|l|}
\hline March, 1995 & Executive Committee meeting of Future Challenges in FP-MCH program for
\end{tabular} integration of ICPD PoA in the Plan for Action approved by NSC.

\begin{tabular}{|l|l|}
\hline June, 1995 & Meeting of the ICPD Task Force. \\
\hline
\end{tabular}

\begin{tabular}{|l|l}
\hline June, 1995 & Formation of Local Working Groups.
\end{tabular}

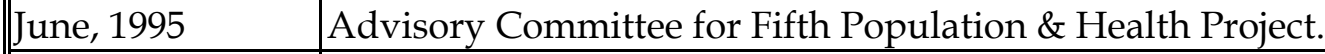

\begin{tabular}{|l|l|}
\hline June, 1995 & Fifth meeting of the Working Group on enhancing collaboration between
\end{tabular}

GO-NGO and private sector discussed and prepared guidelines for GO-

NGO collaboration in the light of ICPD.

\begin{tabular}{|l|l}
\hline August, 1995 & NSC for Future Challenges in the FP-MCH Program issued directives to
\end{tabular} each Working Group to review their own action plan in the context of the recommendation in the ICPD Program of Action.

\begin{tabular}{|l|l}
\hline August, 1995 & Sixth meeting of the Working Group on Critical Training outline of a
\end{tabular} strategy to ensure incorporation of ICPD recommendations into relevant activities.

\begin{tabular}{|l|l||}
\hline August, 1995 & Formation of ICPD National Committee (with most of the Chairpersons and
\end{tabular}

Member-Secretaries of working groups of NSC on Future Challenges in the FP-MCH program).

\begin{tabular}{|l|l}
\hline August, 1995 & Executive Committee decided that working groups would continue to
\end{tabular} function as the formal vehicle for implementation of ICPD Program of Action. 


\begin{tabular}{|c|c|}
\hline Date & Events \\
\hline August, 1995 & $\begin{array}{l}\text { Assess integration of ICPD program of action in the plan for action of the } \\
\text { working groups of NSC. }\end{array}$ \\
\hline November, 1995 & $\begin{array}{l}\text { Regional seminar for policy makers in South Asia and Iran on 'Population } \\
\text { Policies and Quality of Care'. }\end{array}$ \\
\hline November, 1995 & $\begin{array}{l}\text { Discussion about GO-NGO collaboration in the light of ICPD in the 7th } \\
\text { meeting of the Working Group on enhancing Collaboration Between GO- } \\
\text { NGO and Private Sector. }\end{array}$ \\
\hline December, 1995 & $\begin{array}{l}\text { Participatory Research Workshop on "Success of Government-NGO } \\
\text { Collaboration in Population and Development in Bangladesh". }\end{array}$ \\
\hline January, 1996 & $\begin{array}{l}\text { Formation of Review Committee by the Executive Committee of NSC, to } \\
\text { review the functioning of the working groups under NSC. }\end{array}$ \\
\hline March, 1996 & $\begin{array}{l}\text { Formation of Preparatory/Advisory Committee for 5th UNFPA country } \\
\text { program exercise. }\end{array}$ \\
\hline March, 1996 & First Mission for HPSP. \\
\hline April, 1996 & $\begin{array}{l}\text { Approval of "Strategic Directions for the Bangladesh National Family } \\
\text { Planning Program (1995-2005)", GOB. }\end{array}$ \\
\hline $\begin{array}{l}\text { October, } 1994 \text { - } \\
\text { July, } 1996\end{array}$ & $\begin{array}{l}\text { Several meetings of the Working Groups on enhancing collaboration } \\
\text { between GO-NGO and private sector. }\end{array}$ \\
\hline August, 1996 & $\begin{array}{l}\text { National workshop on Reproductive health with a Gender Perspective, } \\
\text { MOHFW. }\end{array}$ \\
\hline $\begin{array}{l}\text { August - } \\
\text { September, } 1996\end{array}$ & Main Mission for the HPSS. \\
\hline August, 1996 & Program Review and Strategy Development Mission, UNFPA. \\
\hline October, 1996 & National Policy on HIV/AIDS and STD. \\
\hline October, 1996 & Workshop on NIPHP results framework. \\
\hline October, 1996 & $\begin{array}{l}\text { Health Sector Review based on the Recommendations of the Platform for } \\
\text { Action of the 4th World Conference on Women. }\end{array}$ \\
\hline December, 1996 & $\begin{array}{l}\text { Technical Workshop to review the Draft National Plan of Action prepared } \\
\text { based on ICPD Recommendations. }\end{array}$ \\
\hline December, 1996 & $\begin{array}{l}\text { Approval of the draft plan of action of the ICPD recommendation emerging } \\
\text { out of the technical workshop. }\end{array}$ \\
\hline February, 1997 & Plan of Action on Safe Blood Transfusion, GOB. \\
\hline March, 1997 & Published National Plan of Action based on ICPD '94 Recommendations. \\
\hline March, 1997 & National Women's Development Policy, MOWCA. \\
\hline September, 1997 & National Reproductive Health Strategy \\
\hline November, 1997 & Publication of NIPHP documents. \\
\hline January, 1998 & HPSP, Program Implementation Plan. \\
\hline January, 1998 & National Food and Nutrition Policy. \\
\hline March, 1998 & The Fifth Five Year Plan (1997-2002), GOB. \\
\hline July, 1998 & $\begin{array}{l}\text { Workshop with the Civil Society to Implement the ICPD Program of Action } \\
\text { (ICPD+5 Round Table). }\end{array}$ \\
\hline
\end{tabular}




\section{Appendix $E$}

\section{Policies and Programs in line with ICPD Programme of Action and major Policy Changes}

\begin{tabular}{|c|c|c|}
\hline $\begin{array}{l}\text { Area(s) of } \\
\text { Action }\end{array}$ & Current Programs and Interventions & Policy Changes \\
\hline \multicolumn{3}{|c|}{ Poverty Alleviation and Sustainable Development } \\
\hline $\begin{array}{l}\text { Rural poverty } \\
\text { alleviation in } \\
\text { order to } \\
\text { minimize the } \\
\text { problem at } \\
\text { source }\end{array}$ & $\begin{array}{l}\text { Rural poverty alleviation programs (145 } \\
\text { thanas) } \\
\text { Rural cooperative projects (TCCA-KSS } \\
\text { System) } \\
\text { Adarsha Gram: Self-reliant ideal villages for } \\
\text { the rehabilitation of landless families } \\
\text { Vulnerable group development and } \\
\text { cooperatives: gender sensitive poverty } \\
\text { alleviation programs } \\
\text { Production and Employment Program for } \\
\text { the rural poor (rural development } \\
\text { projects in } 26 \text { districts): credit, income } \\
\text { generation, self-employment programs } \\
\text { Development and maintenance of physical } \\
\text { infrastructure } \\
\text { Polly Karmashahayak Foundation } \\
\text { Rural Housing } \\
\text { GO/NGO/PVO efforts: credit, income } \\
\text { generation, self-employment, women's } \\
\text { empowerment, education, health and FP, } \\
\text { environment } \\
\text { Massive rural development programs } \\
\text { emphasizing on poverty alleviation }\end{array}$ & $\begin{array}{l}\text { The Fifth Five Year Plan aims to achieve a } \\
\text { high degree of self-reliance. About } 78 \\
\text { percent of the total plan outlay is projected } \\
\text { to be financed from domestic sources. } \\
\text { While poverty alleviation is the over-riding } \\
\text { objective of the plan, generation of } \\
\text { productive employment, achievement of } \\
\text { food self-sufficiency, human resources } \\
\text { development, development of infrastructure, } \\
\text { provision of social amenities, strengthening } \\
\text { of technological base, protection of } \\
\text { environment, closing the gender gap and } \\
\text { establishment of better social justice } \\
\text { through a more equitable distribution of } \\
\text { income are the other national level } \\
\text { objectives of the plan. } \\
\text { Development of national urbanization policy }\end{array}$ \\
\hline Agriculture & $\begin{array}{l}\text { Increasing income earning opportunities } \\
\text { through diversifying crop production; } \\
\text { sustainable agricultural practices } \\
\text { Programs on income generation activities } \\
\text { Promotion of non-farm activities and } \\
\text { alternative programs associated with } \\
\text { agriculture (cottage industries, jute } \\
\text { manufacture/processing, etc.) through } \\
\text { credit support }\end{array}$ & \\
\hline $\begin{array}{l}\text { Industrializa- } \\
\text { tion }\end{array}$ & $\begin{array}{l}\text { Expanding small scale and cottage industries } \\
\text { through reducing credit constraints } \\
\text { Appropriate spatial distribution of activities } \\
\text { through a mix of fiscal and financial } \\
\text { policy packages } \\
\text { Feasibility study for in-country production of } \\
\text { condom and IUD is in place }\end{array}$ & $\begin{array}{l}\text { Massive industrialization policy aiming at a } \\
\text { growth rate of } 8-10 \% \text { per annum } \\
\text { A five member cabinet body formed to } \\
\text { scrutinize new industrial policy } \\
\text { Setting of condom and IUD plants }\end{array}$ \\
\hline $\begin{array}{l}\text { Urbanization, } \\
\text { Migration and }\end{array}$ & $\begin{array}{l}\text { Development of urban areas } \\
\text { Strengthening of capabilities of }\end{array}$ & $\begin{array}{l}\text { Comprehensive master plans for the two } \\
\text { biggest metropolis (Dhaka and Chittagong) }\end{array}$ \\
\hline
\end{tabular}




\begin{tabular}{|c|c|c|}
\hline Environment & $\begin{array}{l}\text { municipalities } \\
\text { Slum Improvement Project, Slum } \\
\text { upgradation, squatter resettlement, Area } \\
\text { redistribution } \\
\text { Water supply and sanitation project } \\
\text { Investment support program for urban poor } \\
\text { Urban poverty alleviation programs } \\
\text { National Environment Management Action } \\
\text { Plan (NEMAP) } \\
\text { Humane approach to forced resettlement } \\
\text { Program for the river eroded people } \\
\text { Targeted poverty alleviation program } \\
\text { Program for migrated population }\end{array}$ & $\begin{array}{l}\text { Plan for improvement of } 10 \text { strategic } \\
\text { secondary towns } \\
\text { National Housing Policy } \\
\text { National Environment Management Policy } \\
\text { Development of National Urbanization policy } \\
\text { "Peace treaty" in Chittagong Hill Tracks } \\
\text { Increase sanitation coverage from current } 40 \% \\
\text { to } 80 \% \text { in } 2000 \text { in the urban area }\end{array}$ \\
\hline $\begin{array}{l}\text { Aging and } \\
\text { disabled } \\
\text { population }\end{array}$ & $\begin{array}{l}\text { Programs on health problems, mentally } \\
\text { handicap, nursing } \\
\text { Pension scheme for the aging people } \\
\text { Observance of the International Elders' Day } \\
\text { Supported Probin Hitayshi Sangha } \\
\text { (organization for the welfare of elderly } \\
\text { persons) } \\
\text { Employment and rehabilitation program for } \\
\text { the disabled } \\
\text { Program for identifying the cause of } \\
\text { disabilities } \\
\text { Special education program for disabled } \\
\\
\text { Various training facilities for disabled } \\
\text { Centre for physically handicapped (ERPH) } \\
\text { at Tongi, existed since } 1981 \\
\text { Construction of "Elders Home," six elder homes } \\
\text { named "Shanti Nibas" at six divisional cities } \\
\text { One shot donation (100 taka per women) to the e } \\
\text { widow and husband abandon women in all } 46 \\
\text { thana of the country (10 women per ward) to } \\
\text { ageing women. The program will benefit abou } \\
403,110 \text { women. } \\
\text { 'Elder remuneration' per month in } 461 \text { rural } \\
\text { thanas }\end{array}$ & $\begin{array}{l}\text { Formation of a National Committee on Aging with } \\
\text { the Minister in charge of the Ministry of Social } \\
\text { Welfare as its chairman } \\
\text { Setting-up of the Institute of Geriatric Medicine at } \\
\text { Dhaka proposed } \\
\text { Construction of "Elders Home" } \\
\text { One shot donation to } 10 \text { women per ward in } 461 \\
\text { rural thana } \\
\text { 'Elder remuneration' to elder person per month }\end{array}$ \\
\hline Marriage & $\begin{array}{l}\text { Social movement against teenage marriage } \\
\text { Programs for increased enrollment of girls in } \\
\text { school } \\
\text { Program for increased involvement of } \\
\quad \text { women in income-generating activities }\end{array}$ & $\begin{array}{l}\text { Government policy regarding minimum age- } \\
\text { at-marriage for males and females } \\
\text { Increase literacy to decrease teenage marriage }\end{array}$ \\
\hline \multicolumn{3}{|c|}{ Health and Family Planning } \\
\hline Health Goals & $\begin{array}{l}\text { Program aiming at reduce IMR to } 50 \text { and under } \\
\quad \text { five mortality rate to } 70 \text { per } 1000 \text { live births } \\
\text { by } 2000 \\
\text { Program aiming at reduce MMR to } 3 \text { per } 1000 \\
\quad \text { live births by } 2000 \\
\text { Program aiming at universal access to safe } \\
\quad \text { drinking water and sanitary means of } \\
\text { excreta disposal } \\
\text { HPSP adopted } \\
\text { Program aiming at reduce severe and moderate }\end{array}$ & $\begin{array}{l}\text { Health policy drafted } \\
\text { HPSP adopted } \\
\text { National Population Policy is underway } \\
\text { National Reproductive Health Strategies adopted } \\
\text { Merging of health and population sector into one } \\
\text { sector } \\
\text { Decentralization of power } \\
\text { Providing ESP services from one stop service point } \\
\text { Limited curative care and control of } \\
\text { communicable diseases }\end{array}$ \\
\hline
\end{tabular}




\begin{tabular}{|c|c|c|}
\hline & $\begin{array}{l}\text { malnutrition among under five children by } \\
\text { half by } 2000 \text { (Bangladesh Integrated } \\
\text { Nutrition Project) } \\
\text { Program aiming at reduce rate of low birth } \\
\text { weight to less than } 10 \% \text { by } 2000 \\
\text { Program aiming at eliminate iodine } \\
\text { deficiency disorders by } 2000 \text { by } 100 \% \text { salt } \\
\text { iodination } \\
\text { Program aiming at access by all pregnant women } \\
\text { to prenatal care, safe delivery, postnatal care } \\
\text { and referral facilities (Safe motherhood } \\
\text { project, EOC project) } \\
\text { Program aiming at } 90 \% \text { complete } \\
\text { immunization of under } 1 \text { children by } 2000 \\
\text { Reduction by one-third in deaths due to ARI } \\
\text { in under-five children } \\
\text { Curative and Preventive Services } \\
\text { Restructuring of health care system in rural areas } \\
\text { Alternative approaches to service delivery } \\
\text { adopted } \\
\text { Program of IEC-Advocacy in changing } \\
\text { community health awareness } \\
\text { Target-free client-need-oriented FP } \\
\text { programs } \\
\text { Strengthening of CDD, ARI, neonatal care } \\
\text { and nutrition programs }\end{array}$ & $\begin{array}{l}\text { Increased allocation to health and FP } \\
\text { Increased allocation for PHCR } \\
\text { Adolescent RH strategies } \\
\text { Reduce IMR to } 50 \text { and under five mortality rate to } \\
70 \text { per } 1000 \text { live births by } 2000 \\
\text { Reduce MMR to } 3 \text { per } 1000 \text { live births by } 2000 \\
\text { Reduce severe and moderate malnutrition } \\
\text { among under five children by half by } 2000 \\
\text { Reduce rate of low birth weight to less than } \\
10 \% \text { by } 2000 \\
\text { Access by all pregnant women to prenatal care, } \\
\text { safe delivery, postnatal care and referral facilities } \\
\text { Direction for Institute well linked referral } \\
\text { system } \\
\text { Diagnosis-referral-treatment of infertility } \\
\text { Reduction by one-third in deaths due to ARI } \\
\text { in under-five children } \\
90 \% \text { complete immunization of under } 1 \\
\text { children by } 2000\end{array}$ \\
\hline $\begin{array}{l}\text { Safe } \\
\text { Motherhood }\end{array}$ & $\begin{array}{l}\text { Safe motherhood initiative and EOC have } \\
\text { only in limited scale } \\
\text { MR Services } \\
\text { Registration of pregnant mothers } \\
\text { Utilization of Trained TBAs } \\
\text { Immunization } \\
\text { Health Education } \\
\text { Safe delivery Kits } \\
\text { Referral } \\
\text { High-risk pregnancy screening } \\
\text { PNC } \\
\text { Emergency Obstetric Care } \\
\text { Hospital and home delivery } \\
\text { Establishment of Thana Health Complex } \\
\text { (Phase II) } \\
\text { Establishment of Institutes of child and } \\
\text { Mother Health } \\
\text { Second Health and Family Planning } \\
\text { Services Project } \\
\text { Functional Improvement of Thana Health } \\
\text { Complex (1st phase } 50 \text { ) } \\
\text { Established five Medical College } \\
\text { Establishment of National Institute of } \\
\text { Kidney Diseases and Urology at Dhaka } \\
\text { Establishment of National Institute of } \\
\text { Cardiovascular Disease in Dhaka city } \\
\text { (Phase II) }\end{array}$ & $\begin{array}{l}\text { In the ESP package caesarean section will be } \\
\text { provide in } 120 \text { THCs, in all MCWCs and all } \\
\text { district hospitals (in the first year of HPSP } \\
35 \text { thana and } 18 \text { MCWCs will be strengthen) } \\
\text { Operational plan for maternal health- } \\
\text { Emergency Obstetric Care } \\
\text { Expansion of EOC upto Union level } \\
\text { Improve quality of MR services, strengthen } \\
\text { IEC, Improve monitoring and management } \\
\text { of complications } \\
\text { Establishment of Institutes/health facilities to } \\
\text { increase access of the vulnerable groups to } \\
\text { health services } \\
\text { Access by all pregnant women to prenatal care, } \\
\text { safe delivery, postnatal care and referral facilities } \\
\text { All delivery attended by trained personnel } \\
\text { Enhance community participation } \\
\text { Legal aspects of reproductive rights and } \\
\text { reproductive health and nutrition high lighted }\end{array}$ \\
\hline
\end{tabular}




\begin{tabular}{|c|c|c|}
\hline $\begin{array}{l}\text { Family } \\
\text { Planning }\end{array}$ & $\begin{array}{l}\text { Mass IEC activities ongoing } \\
\text { Uninterrupted contraceptive supplies } \\
\text { Referral for clinical contraception, Referral } \\
\quad \text { for complications and side-effect } \\
\quad \text { treatment } \\
\text { Follow-up of all clients } \\
\text { Segmented visitation based on unmet need }\end{array}$ & $\begin{array}{l}\text { Population policy adopted } \\
\text { No target to FWAs for family planning } \\
\text { services } \\
\text { No incentive to FWAs for collecting clients for } \\
\text { clinical contraceptives } \\
\text { Self-reliance on production of contraceptives, } \\
\text { highest possible quality of care and services, } \\
\text { meeting unmet need } \\
\text { Increased allocation for family welfare }\end{array}$ \\
\hline $\begin{array}{l}\text { Male } \\
\text { Involvement }\end{array}$ & $\begin{array}{l}\text { Limited IEC activities availabe } \\
\text { Male contraception availabe (condom and } \\
\text { no-scalpel vasectomy) } \\
\text { Innovative interventions on male involvement in } \\
\text { RH decisions }\end{array}$ & Involve male in RH matters \\
\hline $\begin{array}{l}\text { Adolescent } \\
\text { and Child } \\
\text { Welfare }\end{array}$ & $\begin{array}{l}\text { Limited adolescents programs still at pilot } \\
\text { stage } \\
\text { Education related programs undertaken to } \\
\text { provide universal primary and secondary } \\
\text { education, increase enrollment, increase } \\
\text { girls enrollment, decrease dropout } \\
\text { (especially of girls) } \\
\text { Health related programs undertaken to } \\
\text { reduce IMR, morbidity, MMR, night } \\
\text { blindness, iodine deficiency, CDD, EPI, } \\
\text { malnutrition } \\
\text { Income and employment related programs } \\
\text { undertaken } \\
\text { cluded RHE in formal curricula } \\
\text { Curative services made available } \\
\text { Increased employment/self-employment } \\
\text { opportunities for youth } \\
\text { Increased opportunity for skill development } \\
\text { training for adolescents/youths } \\
\text { Program for credit to the youths } \\
\text { School health services are available in } \\
\text { limited scale } \\
\text { Observance of child rights day } \\
\text { Observance of child rights week } \\
\text { Pilot project on birth registration in } 5 \text { district at } \\
\text { union perishad } \\
\text { Awareness program for registration of all } \\
\text { child born after January 1997 } \\
\text { “Sharothi” project (a welfare program for } \\
\text { youth) } \\
\text { Observance of National Youth Festival }\end{array}$ & $\begin{array}{l}\text { Adolescent reproductive health strategies included } \\
\text { in National Reproductive Health Strategies } \\
\text { National children policy adopted } \\
\text { AFLE, to aware adolescent about reproductive } \\
\text { health matters } \\
\text { Prepare youth as skill professional } \\
\text { Make the youth self reliance } \\
\text { One teacher from a school will be trained to } \\
\text { educated students on health matters and } \\
\text { provide first aids } \\
\text { Keep rights of the children } \\
\text { Signatory of the "UN convention on the rights } \\
\text { of the child" } \\
\text { Prevent child trafficking } \\
\text { National program of action on children (1997- } \\
\text { 2002) in the final stage } \\
\text { Universal education; reduce IMR, nutrition, } \\
\text { sanitation, gender equalities, difficult } \\
\text { circumstances (trafficking, prostitution) }\end{array}$ \\
\hline $\begin{array}{l}\text { RTI/STD/HIV/ } \\
\text { AIDS, } \\
\text { Infertility and } \\
\text { other } \\
\text { Reproductive } \\
\text { Health } \\
\text { Services }\end{array}$ & $\begin{array}{l}\text { Limited services for RTI/STD are available } \\
\text { at the grassroot levels } \\
\text { For infertility some IEC services are available, but } \\
\text { no well-knitted service facilities } \\
\text { Cancer, RH for disables are almost non- } \\
\text { existent/Limited services } \\
\text { EPI, satellite clinics, outdoor and indoor } \\
\text { services of hospitals and dispensaries, } \\
\text { FWC }\end{array}$ & $\begin{array}{l}\text { National policy on HIV/AIDS and STD related } \\
\text { issues adopted } \\
\text { Diagnosis, referral, and treatment of infertility } \\
\text { cases } \\
\text { Cancer, RH services for disables } \\
\text { GOB adopted Reproductive health services } \\
\text { including RTI/STD/AIDS as a component of } \\
\text { ESP } \\
\text { Provide full range of referral services at }\end{array}$ \\
\hline
\end{tabular}




\begin{tabular}{|c|c|c|}
\hline & & $\begin{array}{l}\text { district } \\
\text { Reduce more referral and better services } \\
\text { Tertiary, district hospital will be strengthened } \\
\text { and upgraded under HPSP } \\
\text { Construction of } 775 \text { new UHFWCs } \\
\text { Basic Laboratory facilities at UHFWC level } \\
\text { and full facilities at thana and district under } \\
\text { HPSP }\end{array}$ \\
\hline $\begin{array}{l}\text { Child/Infants/ } \\
\text { Neonate }\end{array}$ & $\begin{array}{l}\text { Neonatal care by TTBA and other trained } \\
\text { personnel, Immunization, Breastfeeding, } \\
\text { Nutrition, Vitamin A, Treatment of } \\
\text { common diseases under HPSP }\end{array}$ & $\begin{array}{l}\text { Neo-natal care mainly at domicilliary and } \\
\text { union level }\end{array}$ \\
\hline \multicolumn{3}{|c|}{ Research, Training and Information } \\
\hline $\begin{array}{l}\text { Generation, } \\
\text { analyze, } \\
\text { dissemination } \\
\text { of newer } \\
\text { information } \\
\text { through } \\
\text { research }\end{array}$ & $\begin{array}{l}\text { MIS for Program Data Collection } \\
\text { BBS for demographic and health related } \\
\text { information } \\
\text { Periodic CPS/DHS } \\
\text { Social and epidemiological research on RH } \\
\text { and contraceptive } \\
\text { Operations Research } \\
\text { BMRC is providing support to the researcher } \\
\text { of the medical institute } \\
\text { Short and long-term training for the } \\
\text { researchers }\end{array}$ & $\begin{array}{l}\text { In order to support HPSP, NIPORT, BMRC, } \\
\text { NIPSOM, IEDCR and BIRPERHT will } \\
\text { provide training and undertake research } \\
\text { except other organization } \\
\text { Will form a Research Co-ordination Committee } \\
\text { (RCC) to co-ordinate all research } \\
\text { Will introduce Vital registration system } \\
\text { throughout the country } \\
\text { Will generate gender desegregated data, } \\
\text { incorporate RH service indicators in MIS } \\
\text { Will conduct regular and timely } \\
\text { dissemination of research findings to } \\
\text { appropriate target group at all levels } \\
\text { Will provide short and long-term training for } \\
\text { the researchers }\end{array}$ \\
\hline \multicolumn{3}{|c|}{ Education } \\
\hline $\begin{array}{l}\text { Education is } \\
\text { for sustainable } \\
\text { development } \\
\text { and the } \\
\text { improvement } \\
\text { in the quality } \\
\text { of life }\end{array}$ & $\begin{array}{l}\text { Primary education made compulsory in } \\
\text { order to attain the goal of education for all } \\
\text { by } 2000 \\
\text { Food for Education Program introduced } \\
\text { Enrollment increased to } 87 \text { percent and } \\
\text { dropout reduced } \\
\text { Stipends to all female students up to grade } \\
10 \\
\text { Separate hostel buildings for girl students in } \\
\text { TTC and PTIs } \\
\text { Separate Vocational Training Institute and } \\
\text { Polytechnic Institutes for girls } \\
\text { Programs taken up to increase adult literacy } \\
\text { rate to } 62 \% \text { by } 2000 \text { A.D. } \\
\text { Vocational and technical education provided } \\
\text { for career development } \\
\text { Population education and topics related to } \\
\text { gender, FLE, health, AIDS included in } \\
\text { textbooks } \\
\text { Some family life concepts introduced in books of } \\
\text { the non-formal sector } \\
\text { Demography taught in few departments of } \\
\text { the universities } \\
\text { Establishment of medical university }\end{array}$ & $\begin{array}{l}\text { National education policy proposed and } \\
\text { constituted of } 6 \text { members committee on } 17 \\
\text { January } 1997 \text {. } \\
\text { Mass education and universal primary } \\
\text { education } \\
\text { Increase gross enrollment rate of primary } \\
\text { school-age population to } 95 \% \text { by the end of } \\
\text { year } 2000 \text { with particular emphasis on girls } \\
\text { Stipends to all female students up to grade } 10 \\
\text { Recruitment of } 60 \% \text { female teachers at the } \\
\text { primary school level, } 40 \text { percent at } \\
\text { secondary level and } 10 \text { percent at college } \\
\text { and university level } \\
\text { Increase primary cycle completion rate to } 70 \% \\
\text { by } 2000 \\
\text { Increase adult literacy rate to } 62 \% \text { by } 2000 \\
\text { Expansion of education facilities for } \\
\text { disadvantaged groups } \\
\text { In the proposed education policy, teacher } \\
\text { students ratio will be } 1: 40 \text { at the primary } \\
\text { level, 1:12 at the vocational training } \\
\text { institute } \\
\text { Policy for initiation of MSc. course in } \\
\text { Nursing college }\end{array}$ \\
\hline
\end{tabular}




\begin{tabular}{|c|c|c|}
\hline & & $\begin{array}{l}\text { Enhanced involvement of NGOs in achieving } \\
\text { UPE and secondary education goals }\end{array}$ \\
\hline $\begin{array}{l}\text { Greater public } \\
\text { knowledge, } \\
\text { understanding } \\
\text { and } \\
\text { commitment } \\
\text { necessary to } \\
\text { respond } \\
\text { positively to } \\
\text { population } \\
\text { concerns }\end{array}$ & $\begin{array}{l}\text { Programs to inform, educate and motivate } \\
\text { adults taken up } \\
\text { Special programs for religious groups, } \\
\text { youths, journalists etc. are ongoing } \\
\text { IEC Program for MPs to promote awareness } \\
\text { on issues related to population and } \\
\text { development being designed } \\
\text { Adults literacy program } \\
\text { Expand population concepts to other } \\
\text { spheres of education } \\
\text { Ensure higher use of entertainment media } \\
\text { and IEC }\end{array}$ & $\begin{array}{l}\text { Increased adult literacy } \\
\text { Improve curriculum of vocational and } \\
\text { polytechnic institutes to come-up with } \\
\text { market demands and increase prospects of } \\
\text { gainful employment } \\
\text { Increase intake to } 25 \% \text { female students and } \\
\text { teachers in the VTIs and technical institutes } \\
\text { Upgradation of population education } \\
\text { curricula with adequate coverage of RH, } \\
\text { FLE, Gender, HIV/AIDS, domestic } \\
\text { violence, child trafficking, etc. } \\
\text { Form committee at the MOE to coordinate } \\
\text { and monitor PopEd } \\
\text { Constitute National IEC Committee } \\
\text { Promotion of universal education upto } \\
\text { secondary level (say by 2005), particularly } \\
\text { for females }\end{array}$ \\
\hline \multicolumn{3}{|c|}{ Women's Development and Empowerment } \\
\hline $\begin{array}{l}\text { Policy-making } \\
\text { institutions } \\
\text { and women } \\
\text { representation } \\
\text { at the policy } \\
\text { levels }\end{array}$ & $\begin{array}{l}\text { Creation of Ministry of Women and Children } \\
\text { Affairs } \\
\text { Creation of Department of Women Affairs } \\
\text { Formation of National Council for Women's } \\
\text { Development (NCWD Chaired by the } \\
\text { Hon'ble Prime Minister) } \\
\text { Dormitory for working women and street } \\
\text { children } \\
\text { Enforcement of policy on legal age at } \\
\text { marriage } \\
\text { Enforcement of women empowering acts } \\
\text { Formation of interministerial committees } \\
\text { for women development } \\
\text { National integrated gender sensitive } \\
\text { development programs }\end{array}$ & $\begin{array}{l}\text { National Women Development Policy } \\
\text { adopted } \\
10 \% \text { Women quota at the parliament } \\
\text { Increased women quota in public } \\
\text { administration } \\
\text { Women representation at the Local } \\
\text { Government Bodies } \\
\text { Increase intake to } 25 \% \text { female students and } \\
\text { teachers in the VTIs and technical } \\
\text { institutes } \\
\text { Policy for Women and program of action } \\
\text { adopted based on PFA } \\
\text { One shot donation to } 10 \text { women per ward in } 461 \\
\text { rural thana }\end{array}$ \\
\hline $\begin{array}{l}\text { Legal } \\
\text { measures to } \\
\text { protect } \\
\text { women-child } \\
\text { interest }\end{array}$ & $\begin{array}{l}\text { Women empowering acts (Dowry } \\
\text { Prohibition Act) (1980) } \\
\text { Cruelty to Women (Deterrent Punishment } \\
\text { Act, 1983) } \\
\text { Muslim Family Ordinance } 1961 \text { (Amended } \\
\text { 1985) } \\
\text { Penal Code (Second Amendment Ordinance) } \\
\text { Family Court Ordinance } 1985 \\
\text { Government policy on legal age at marriage } \\
\text { Child Marriage Restraint Act, } 1984 \\
\text { Anti-Terrorism Ordinance, } 1992 \\
\text { Advocacy campaign and IEC on legal } \\
\quad \text { measures, sensitizing judicial and law } \\
\text { enforcing agencies } \\
\text { Programs to minimize illegal traffickng } \\
\text { Special courts for women } \\
\text { Formation of Interministerial Committees } \\
\text { Create for special courts }\end{array}$ & $\begin{array}{l}\text { Special courts for women } \\
\text { Review legal issues specially those affecting } \\
\text { women }\end{array}$ \\
\hline
\end{tabular}




\begin{tabular}{|c|c|c|}
\hline $\begin{array}{l}\text { Economic and } \\
\text { Social } \\
\text { empowerment }\end{array}$ & $\begin{array}{l}\text { Employment in Health and FP sector } \\
\text { Gender sensitive health service facilities } \\
\text { Women focused poverty alleviation } \\
\text { programs } \\
\text { Vulnerable group development } \\
\text { Rural Cooperatives } \\
\text { GO/NGO/PVO efforts; credit, income } \\
\text { generation, self-employment } \\
\text { Investment support program for urban poor } \\
\text { Urban poverty alleviation program } \\
\text { Programs on providing credit supports and } \\
\text { skill development for females } \\
\text { Scholarship (stipend) programs for } \\
\text { secondary school girls } \\
\text { Family Life Education } \\
\text { Limited baby sitting at the office premises } \\
\text { One shot donation (100 taka per women) to the } \\
\text { elderly, widow and husband abandon women } \\
\text { in all } 461 \text { rural thana of the country (10 } \\
\text { women per ward). The program will benefit } \\
\text { about } 403,110 \text { women. } \\
\text { Construction of } 12 \text {-storied building complex for } \\
\text { office, legal aid center, women hostel, day care } \\
\text { center, auditorium, bank, sale and display } \\
\text { center and health center }\end{array}$ & $\begin{array}{l}\text { Employment quota ( } 60 \% \text { ) for primary school } \\
\text { teachers, } 15 \% \text { at non-gazette level and } 10 \% \\
\text { at officers level } \\
\text { Mass education and universal primary } \\
\text { education } \\
\text { Increase gross enrollment rate of primary } \\
\text { school-age population to } 95 \% \text { by the end of } \\
\text { year } 2000 \text { with particular emphasis on girls } \\
\text { Increase primary cycle completion rate to } 70 \% \\
\text { by } 2000 \\
\text { Increase adult literacy rate to } 62 \% \text { by } 2000 \\
\text { Non-formal education for girls } \\
\text { Mandatory marriage registration system }\end{array}$ \\
\hline \multicolumn{3}{|c|}{ GO-NGO-Private Sector Collaboration } \\
\hline & $\begin{array}{l}\text { High level committee for GO-NGO collaboration } \\
\text { is in place supported by Task Force } \\
\text { Fourth Population and Health Project, HAPP-5 } \\
\text { and NIPHP } \\
\text { ADB Second Health and Population Project for urban } \\
\text { primary health care } \\
\text { Community cost sharing, service charges and cost } \\
\text { savings by NGOs } \\
\text { Transportation of logistics through private sector } \\
\text { channel partly established } \\
\text { Mechanism for quality control of clinical services } \\
\text { established } \\
\text { National Steering Committee for Future } \\
\text { challenges in FP and formation of working group } \\
\text { for FP-MCH activities with NGOs } \\
\text { District and Thana level FP Committees with } \\
\text { NGOs } \\
\text { National Population Council, representation from } \\
\text { NGOs } \\
\text { National Committee for ICPD follow-up with } \\
\text { NGOs } \\
\text { Plan of action for implementation of ICPD } \\
\text { recommendations with NGOs } \\
\text { Sub-grants to the NGO to implement government } \\
\text { programs } \\
\text { Participation of the NGO and private sector in the } \\
\text { government programs }\end{array}$ & $\begin{array}{l}\text { Formation of GNCC } \\
\text { Commitment to 4th Population and Health Project, } \\
\text { HPSP and NIPHP } \\
\text { Improve urban primary health specially for the } \\
\text { vulnerable groups through GO-NGO collaboration } \\
\text { Better collaboration with NGOs to foster sustainable } \\
\text { development } \\
\text { Formation of NGO-CC headed by DG/DFP } \\
\text { Sustain policy level commitment; ensure more } \\
\text { active involvement of peoples representatives } \\
\text { and community leaders, etc } \\
\text { Commitment of Contraceptive Supply through } \\
\text { development partners } \\
\text { Allocation of areas to NGOs for service delivery } \\
\text { Coordination in resource mobilization through } \\
\text { GOB, NGOs, donors } \\
\text { Involvement of NGOs and private sector in training, } \\
\text { management, financial and institutional capacity } \\
\text { building for implementation of reproductive health } \\
\text { issues } \\
\text { Uniform logistics for GO/NGO } \\
\text { Collaboration in undertaking joint programs for } \\
\text { planning, implementation and monitoring at all } \\
\text { levels. } \\
\text { Bilateral donation with contribution from GOB and } \\
\text { NGOs }\end{array}$ \\
\hline
\end{tabular}

Note: Most of the contents are derived from National Plan of Action based on ICPD Recommendation. (MOHFW, 1997). Italic components indicate those influenced (to various degrees) by ICPD '94. 


\section{List of Abbreviations}

\begin{tabular}{|c|c|}
\hline $\mathrm{ADB}$ & Asian Development Bank \\
\hline ARI & Acute Respiratory Infections \\
\hline BCC & Behaviour Change Communication \\
\hline BCS & Behavioural Change Support \\
\hline BINP & Bangladesh Integrated Nutrition Project \\
\hline BIRPERHT & $\begin{array}{l}\text { Bangladesh Institute of Research for Promotion of Essential and } \\
\text { Reproductive Health and Technologies }\end{array}$ \\
\hline CPR & Contraceptive Prevalence Rate \\
\hline CWFP & Concerned Women for Family Planning \\
\hline EOC & Emergency Obstetric Care \\
\hline EPI & Expanded Program on Immunization \\
\hline ESP & Essential Services Package \\
\hline FFYP & Fifth Five Year Plan \\
\hline FPHP & Fourth Population and Health Project \\
\hline FWA & Family Welfare Assistant \\
\hline FWC & Family Welfare Centre \\
\hline GOB & Government of Bangladesh \\
\hline HIV & Human Immunodeficiency Virus \\
\hline HPSP & Health and Population Sector Program \\
\hline HPSS & Health and Population Sector Strategy \\
\hline ICPD & International Conference on Population and Development \\
\hline IEC & Information-Education-Communication \\
\hline IMC & Integrated Management of Childhood Illness \\
\hline IMR & Infant Mortality Rate \\
\hline ISBT & International Society for Blood Transfusion \\
\hline IUD & Intra Uterine Device \\
\hline LGRD & Local Government and Rural Development \\
\hline $\mathrm{MCH}$ & Maternal \& Child Health \\
\hline MCWC & Maternal and Child Welfare Centre \\
\hline MIS & Management Information System \\
\hline MMR & Maternal Mortality Rate \\
\hline MOE & Ministry of Education \\
\hline MOHFW & Ministry of Health \& Family Welfare \\
\hline MOWCA & Ministry of Women and Children's Affairs \\
\hline MR & Menstrual Regulation \\
\hline NCWD & National Council for Womens Development \\
\hline NGO & Non-government Organization \\
\hline NIPHP & National Integrated Population and Health Program \\
\hline NPA & National Plan of Action \\
\hline
\end{tabular}


NSC

PIP

PoA

$\mathrm{RH}$

RTI

STD

SWM

TBA

TFR

THC

UNFPA

UNICEF

UPE

USAID

WHO
National Steering Committee

Program Implementation Plan

Program of Action (of ICPD'94)

Reproductive Health

Reproductive Tract Infection

Sexually Transmitted Disease

Sector-wide Management

Traditional Birth Attendant

Total Fertility Rate

Thana Health Complex

United Nations Population Fund

United Nations Children Fund

Universal Primary Education

United States Agency for International Development

World Health Organization 
